\title{
Past and present of sediment and carbon biogeochemical cycling models
}

\author{
F. T. Mackenzie ${ }^{1}$, A. Lerman $^{2}$, and A. J. Andersson ${ }^{1}$ \\ ${ }^{1}$ Department of Oceanography, University of Hawaii, Honolulu, Hawaii 96822, USA \\ ${ }^{2}$ Department of Geological Sciences, Northwestern University, Evanston, Illinois 60208, USA
}

Received: 25 April 2004 - Published in Biogeosciences Discussions: 24 May 2004

Revised: 1 August 2004 - Accepted: 10 August 2004 - Published: 20 August 2004

\begin{abstract}
The global carbon cycle is part of the much more extensive sedimentary cycle that involves large masses of carbon in the Earth's inner and outer spheres. Studies of the carbon cycle generally followed a progression in knowledge of the natural biological, then chemical, and finally geological processes involved, culminating in a more or less integrated picture of the biogeochemical carbon cycle by the 1920s. However, knowledge of the ocean's carbon cycle behavior has only within the last few decades progressed to a stage where meaningful discussion of carbon processes on an annual to millennial time scale can take place. In geologically older and pre-industrial time, the ocean was generally a net source of $\mathrm{CO}_{2}$ emissions to the atmosphere owing to the mineralization of land-derived organic matter in addition to that produced in situ and to the process of $\mathrm{CaCO}_{3}$ precipitation. Due to rising atmospheric $\mathrm{CO}_{2}$ concentrations because of fossil fuel combustion and land use changes, the direction of the air-sea $\mathrm{CO}_{2}$ flux has reversed, leading to the ocean as a whole being a net sink of anthropogenic $\mathrm{CO}_{2}$. The present thickness of the surface ocean layer, where part of the anthropogenic $\mathrm{CO}_{2}$ emissions are stored, is estimated as of the order of a few hundred meters. The oceanic coastal zone net air-sea $\mathrm{CO}_{2}$ exchange flux has also probably changed during industrial time. Model projections indicate that in preindustrial times, the coastal zone may have been net heterotrophic, releasing $\mathrm{CO}_{2}$ to the atmosphere from the imbalance between gross photosynthesis and total respiration. This, coupled with extensive $\mathrm{CaCO}_{3}$ precipitation in coastal zone environments, led to a net flux of $\mathrm{CO}_{2}$ out of the system. During industrial time the coastal zone ocean has tended to reverse its trophic status toward a non-steady state situation of net autotrophy, resulting in net uptake of anthropogenic $\mathrm{CO}_{2}$ and storage of carbon in the coastal ocean, despite the significant calcification that still occurs in this region. Fur-
\end{abstract}

Correspondence to: A. Lerman

(alerman@northwestern.edu) thermore, evidence from the inorganic carbon cycle indicates that deposition and net storage of $\mathrm{CaCO}_{3}$ in sediments exceed inflow of inorganic carbon from land and produce $\mathrm{CO}_{2}$ emissions to the atmosphere. In the shallow-water coastal zone, increase in atmospheric $\mathrm{CO}_{2}$ during the last 300 years of industrial time may have reduced the rate of calcification, and continuation of this trend is an issue of serious environmental concern in the global carbon balance.

\section{Introduction}

Our understanding of the behavior of carbon in nature, as the main chemical constituent of life on Earth, has progressed through observations and modeling of the short-term processes of formation and decay of living organic matter by the land and oceanic biotas, the somewhat longer processes of carbon cycling in the oceans, and the geologically much longer time scales of the sedimentary cycle that involves deposition of sediments on the ocean floor and their subsequent migration to the mantle and reincorporation in the continental mass.

In the early 1970s, Garrels and Mackenzie (1972) published a model describing the steady state cycling of eleven elements involved in the formation and destruction of sedimentary rocks: $\mathrm{Al}, \mathrm{C}, \mathrm{Ca}, \mathrm{Cl}, \mathrm{Fe}, \mathrm{K}, \mathrm{Mg}, \mathrm{Na}, \mathrm{S}, \mathrm{Si}$, and $\mathrm{Ti}$. To our knowledge, this was the first modern attempt to model comprehensively and interactively the biogeochemical cycles of the major elements in the ocean-atmosphere-sediment system. The model, incorporating much of the basic thinking advanced in "Evolution of Sedimentary Rocks" (Garrels and Mackenzie, 1971), derived a steady state mass balance for the sedimentary system consistent with the observed composition of the atmosphere, biosphere, ocean, stream and groundwater reservoirs, as well as the ages and average composition of sedimentary rocks. Of importance to the present paper with respect to the carbon balance were the conclusions from 
the Garrels and Mackenzie model that on the geologic time scale (1) the global oceans are generally a net heterotrophic system, with the sum of aerobic and anaerobic respiration exceeding the gross production of organic matter in the ocean and hence are a source of $\mathrm{CO}_{2}$, reflecting the imbalance in the fluxes related to these processes, and (2) the oceans must act as a source of $\mathrm{CO}_{2}$ to the atmosphere from the processes of carbonate precipitation and accumulation.

In this paper we explore some of the more recent developments related to these conclusions in the context of the history of modeling of the carbon cycle, and what models tell us about the pre-industrial to future air-sea transfers of $\mathrm{CO}_{2}$ in the shallow-ocean environment.

\section{History of modeling concepts of the carbon cycle}

Perceptions of many natural processes as cycles are undoubtedly rooted in the changes of day and night, seasons of the year, and astronomical observations in ancient times, from which the concept of cycles and epicycles of planetary motions emerged. Another cyclical phenomenon of great importance, but less obvious to the eye, is the cycle of water on Earth that is also responsible for the circulation and transport of many materials near and at the Earth surface. An early description of the water cycle is sometimes attributed to a verse in the book of "Ecclesiastes" (i, 7), believed to have been written in the 3rd century B.C., that speaks of the rivers running into the sea and returning from there to their place of origin (but there is no mention of the salt nor of water evaporation and precipitation). The modern concept of the global water cycle is the result of observations of atmospheric precipitation, its infiltration into the ground, river runoff, and experiments on water evaporation conducted in the 1600s in France and England (Linsey, 1964). These concepts were well accepted by the time of the first edition of Charles Lyell's "Principles of Geology" (Lyell, 1830, p. 168). By 1872, Lyell referred to a cycle - "the whole cycle of changes returns into itself" - in his description of alternating generations of asexual and sexual reproduction among certain classes of marine invertebrates, which he likened to metamorphosis in insects (Lyell, 1872, p. 329; 1875, p. 329).

As to geochemical cycles, an early treatment of the subject appeared in 1875, where several chapters on the cycles of chemical elements were included in a book on Earth history by Friedrich Mohr, a professor at the University of Bonn, with chapters on the silicon and carbon cycles among them (Mohr, 1875, pp. 397-398). Since then and to the early part of the 20th century, the cyclical nature of the major geological processes, that involve shaping of the Earth surface by tectonic forces and running water, and transfer of molten rock material from depth to the surface, developed into a well accepted concept.

The earlier discoveries that plants use carbon dioxide for growth in sunlight and return it to the atmosphere in dark- ness must have been the first scientific observations of one important part of the carbon cycle. A step further in the carbon cycle was that living plants use carbon dioxide to make their tissues, and when they die they become organic matter in soil that decomposes to carbon dioxide. The formation of organic matter from carbon dioxide and water under the action of light, the process known as photosynthesis, has been studied since the latter part of the 1700s, when molecular oxygen was discovered in the process and carbon dioxide identified as a component of air. Short histories of successive discoveries in photosynthesis, since the late 1700s to the 20th century, have been given by several authors (Gaffron, 1964; Meyer, 1964, p. 21; Bassham, 1974; Whitmarsh and Govindjee, 1995). Presentation of the first general scheme of the carbon and nitrogen cycles has been attributed to the French chemist, Jean Baptiste André Dumas, in 1841 (Rankama and Sahama, 1950, p. 535).

By the early 20th century, concepts of the cycles of the biologically important elements began to recognize their interactions and expanded to include the various physical, chemical, geological, and biological processes on Earth, and the material flows between living organisms and their surroundings, as well as between different environmental reservoirs. In the 1920s, the cycles of the chemical elements that are involved in biological processes - carbon, nitrogen, and phosphorus - and are also transported between soil, crustal rocks, atmosphere, land, and ocean waters, and the Earth's interior were sufficiently well recognized. Alfred Lotka wrote in his book "Elements of Physical Biology", published in 1925, chapters on the cycles of carbon dioxide, nitrogen, and phosphorus that present a modern treatment of what we call today the biogeochemical cycles (Lotka, 1925). Furthermore, he wrote that his ideas of the nutrient element cycles and mathematical treatment of biogeochemical problems were developed as far back as 1902 and in his publications starting in 1907. The term biogeochemical reflects the fact that biological, physical, geological, and chemical processes play important roles and interact with each other in the element cycles that are mediated by photosynthetic primary production and respiration or mineralization of organic matter.

By 1950, the geochemical cycles of elements in the Earth interior and on its surface became textbook material (Rankama and Sahama, 1950), having a variable degree of detail for each cycle that reflected the uneven knowledge of igneous and sedimentary reservoirs and some of the interreservoir fluxes at the time. This early, if not first, systematic textbook treatment of the geochemical cycles presented diagrams of the geochemical reservoirs as boxes and fluxes between them, and tabulations of the elemental concentrations or masses in some of the individual reservoirs. Also, plant and animal ecosystems began to be represented as models of a varying degree of detail based on systems of reservoirs (ecosystem components) and inter-reservoir fluxes (transfers of material or energy) (e.g. Odum, 1983). Subsequent decades produced the knowledge we have today of the chem- 
ical speciation of the elements in the different compartments of the Earth, their abundances, and mechanisms responsible for their flows. While the earlier models of the global biogeochemical cycles of individual elements were static, describing the cycles without their evolution in time, developments in the mathematical treatment of time-dependent multireservoir systems (e.g. Meadows et al., 1972) found their application in the analysis of geochemical cycles (e.g. Lerman et al., 1975). Since then, there has been a great proliferation of cycle models, and in particular of carbon cycle models, at very different physical and time scales, aimed at interpretation of cycle evolution in the past and its projection into the future for the world as a whole, as well as for such global reservoirs as the atmosphere, land, coastal oceanic zone, and the open ocean.

Considerable attention has been focused on the global sedimentary cycle and the cycling of salts in the ocean as a result of Kelvin's (William Thomson, later Lord Kelvin) estimates of the age of the Earth between 24 and $94 \mathrm{Ma}$, made between 1864 and 1899 (Carslaw and Jaeger, 1959, pp. 85-87), and the estimates of the age of the ocean from the rate of accumulation of sodium brought in by rivers, as was done, for example, by Joly (1899) whose estimated age of the ocean was about $90 \mathrm{Ma}$. Recognition of the importance of crustal denudation and sediment transport as ongoing geological processes on a global scale is attributed to James Hutton (17261797). Gregor (1988, 1992) summarized and discussed in detail the geological arguments in the second half of the 1800 s and the early 1900 s for the recycling of oceanic sediments after their deposition (Croll, 1871) and for the existing sinks of dissolved salts in ocean water, such as their removal by adsorption on clays, entrapment in sediment pore water, and formation of evaporites, all of which were contrary to the idea of the ocean continuously filling up with dissolved salts (Hunt, 1875; Fisher, 1900; Becker, 1910). Garrels and Mackenzie (1971) presented the concepts of the sedimentary cycling of materials, that had laid dormant for some years, in book form, and in 1972 these two authors developed a quantitative model of the complete sedimentary rock cycle. Quantitative estimates of sediment recycling rates, based on mass-age sediment distributions, have been made by Gregor (1970, 1980) and Garrels and Mackenzie (1971, 1972): the total sedimentary mass has a mass half-age of $600 \mathrm{Ma}$. The differential weathering rates of different rock types gave the half-age of shales and sandstones of about $600 \mathrm{Ma}$, longer than the ages of more easily weathered rocks, such as carbonates of half-age $300 \mathrm{Ma}$ and evaporites of about $200 \mathrm{Ma}$. Later work (Veizer, 1988) showed that the recycling rates of the sedimentary lithosphere and the various rock types within it are mainly a function of the recycling rates of the tectonic realms, such as active margin basins, oceanic crust, and continental basement, in which the sediments were accumulated.
Table 1. Masses of carbon $(\mathrm{C}$, in grams) in the major Earth reservoirs.

\begin{tabular}{|c|c|}
\hline Upper mantle $^{1)}$ & $(8.9$ to 16.6$) \times 10^{22}$ \\
\hline Oceanic crust ${ }^{2}$ ) & $9.200 \times 10^{20}$ \\
\hline Continental crust ${ }^{3)}$ & $2.576 \times 10^{21}$ \\
\hline Endogenic reservoirs & $\sim 13.1 \times 10^{22}$ \\
\hline Sediments 4 ) & $7.780 \times 10^{22}$ \\
\hline Carbonates & $6.53 \times 10^{22}$ \\
\hline Organic matter & $1.25 \times 10^{22}$ \\
\hline Ocean $^{5)}$ & $3.850 \times 10^{19}$ \\
\hline Atmosphere $^{6)}$ & $7.850 \times 10^{17}$ \\
\hline Exogenic reservoirs & $7.784 \times 10^{22}$ \\
\hline Land phytomass 7 ) & $6 \times 10^{17}$ \\
\hline Soil humus (old and reactive) ${ }^{8)}$ & $1.5 \times 10^{18}$ \\
\hline Oceanic biota $^{9}$ ) & $\sim 3 \times 10^{15}$ \\
\hline
\end{tabular}

1) Upper mantle data from compilation by Li (2000, p. 212) and Wood et al. (1996). The mass of the upper mantle down to the depth of $700 \mathrm{~km}$, representing $18.5 \%$ of the Earth mass, is $1,110 \times 10^{24} \mathrm{~g}$ (Li, 2000).

2) Mass of oceanic crust: $6.5 \mathrm{~km} \times 3.61 \times 10^{8} \mathrm{~km}^{2} \times 2.7 \mathrm{~g} / \mathrm{cm}^{3}=6.57$

$\times 10^{24}$ g. Carbon concentration from $\mathrm{Li}(2000$, p. 222).

3) Mass of continental crust: $30 \mathrm{~km} \times 1.49 \times 10^{8} \mathrm{~km}^{2} \times 2.5 \mathrm{~g} / \mathrm{cm}^{3}=$ $11.2 \times 10^{24} \mathrm{~g}$. Carbon concentration from $\mathrm{Li}(2000$, p. 227).

4) Total sediment mass (continental and oceanic) $2.09 \times 10^{24} \mathrm{~g}(\mathrm{Li}$, 2000, p. 269). Other estimates: $1.7 \times 10^{24} \mathrm{~g}$ (Poldervaart, 1955),

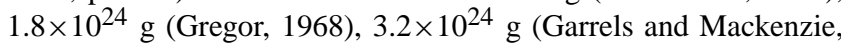
1971), $2.7 \times 10^{24}$ (Ronov, 1980).

5) From species concentrations in gram/liter (Li, 2000, p. 304) and ocean volume $1.37 \times 10^{21}$ liter.

6) Present-day atmosphere, $370 \mathrm{ppmv} \mathrm{CO}_{2}$. Pre-industrial atmosphere is 280 ppmv $\mathrm{CO}_{2}$.

7) Ver et al. (1999).

8) Ver (1998).

9) Lerman et al. (1989), Ver (1998).

\section{Carbon cycle in the Earth interior and on the surface}

Geochemical cycles involving the interior of the Earth are known as endogenic cycles, and they are generally characterized by long time scales of the orders of $10^{8}$ to $10^{9}$ years. The sediments, hydrosphere, biosphere, and atmosphere are grouped in the exogenic cycle, and a few authors define the exogenic cycle as the reservoirs of the biosphere, hydrosphere, and atmosphere, relegating the sediments to the endogenic cycle. A summary of the carbon content of the major endogenic and exogenic reservoirs is given in Table 1. Among the endogenic reservoirs, the upper mantle is the largest reservoir of carbon and its carbon content exceeds that of all the exogenic reservoirs. On the Earth surface, the sediments are by far the largest carbon reservoir containing carbonate sediments and rocks, mostly calcite and dolomite, and organic matter. The mass of carbon in known fossil fuel reserves (different types of coal, petroleum, and 


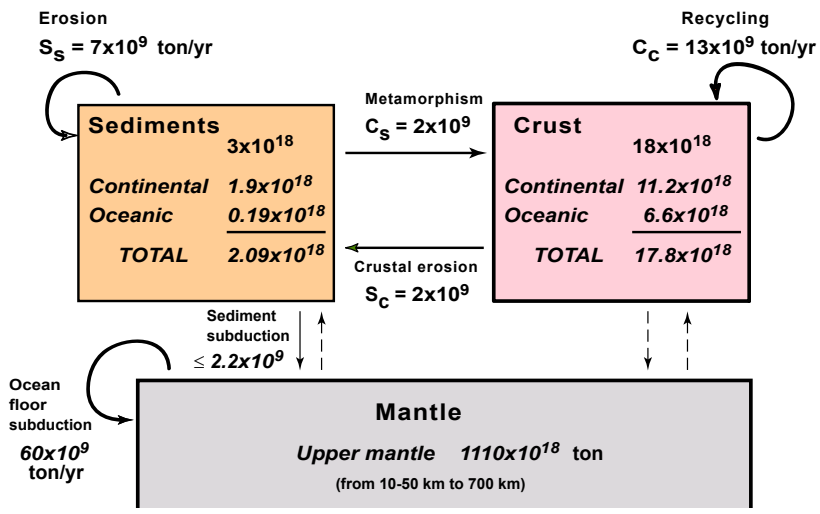

Fig. 1. Gregorian rock cycle (Gregor, 1988). Reservoir masses shown in italics from Li (2000), oceanic crust subduction rate from Mottl (2003), and further details in the text. Reservoir masses are in units of ton and fluxes in units of ton $\mathrm{yr}^{-1}\left(1\right.$ ton $\left.=10^{6} \mathrm{~g}\right)$.

hydrocarbon gases) amounts to a very small fraction, less than $0.5 \%$, of sedimentary organic carbon. The ocean contains about 50 times as much carbon as the present-day atmosphere, which makes it an important reservoir for exchange with atmospheric $\mathrm{CO}_{2}$ under changing environmental conditions that may affect the $\mathrm{CO}_{2}$ solubility in ocean water. Land plants contain a mass of carbon comparable to that of the atmosphere, and the two carbon reservoirs would have been nearly of equal mass in pre-industrial time when atmospheric $\mathrm{CO}_{2}$ stood at 280 ppmv. The similar masses of carbon in land plants and the atmosphere suggest that rapid and strong changes in land vegetation cover, such as due to extensive fires or epidemic mortality, might be rapidly reflected in a rise of atmospheric $\mathrm{CO}_{2}$. Although the carbon mass in oceanic primary producers amounts to $1 / 200$ of land plants, the roles of the two biotas in the fixation of carbon by primary production are comparable: net primary production on land is $63 \times 10^{9}$ ton $\mathrm{C} / \mathrm{yr}\left(5250 \times 10^{12} \mathrm{~mol} / \mathrm{yr}\right)$, as compared with 37 to $45 \times 10^{9}$ ton $\mathrm{C} / \mathrm{yr}\left(3100\right.$ to $\left.3750 \times 10^{12} \mathrm{~mol} / \mathrm{yr}\right)$ in the ocean, resulting in a much shorter turnover or residence time of carbon in oceanic biota (e.g. Schlesinger, 1997; Mackenzie, 2003).

\subsection{The global rock cycle}

The carbon cycle is part of the much bigger rock cycle that includes deeper as well as the outer Earth shells. The rock cycle is a conceptual model of material transfers between the Earth interior and its surface or, more specifically, between the mantle, crystalline crust, sedimentary rocks, and younger unconsolidated sediments. A model of the rock cycle that shows the essentials of sediment formation and recycling is given in Fig. 1. Sediments are formed mainly by erosion of crustal rocks (flux $\mathrm{S}_{c}$ ), and they are recycled by erosion, redeposition, and continental accretion (flux $\mathrm{S}_{S}$ ). Sediments are returned to the crystalline crust by metamorphism (flux
$\mathrm{C}_{S}$ ) and to the upper mantle by subduction of the ocean floor. The more recent estimates of the masses of sediments, continental and oceanic crust, and upper mantle differ somewhat from those used by Gregor (1988), as shown in italics for the reservoirs in Fig. 1, but they do not affect the conceptual nature of the rock cycle and its fluxes. Although neither the water reservoirs nor flows are shown in the rock cycle of Fig. 1, they are implicit in the diagram as the main transport agents that are responsible for the chemically reactive and physical material flows within the system.

The sediment recycling rate, $\mathrm{S}_{s}=7 \times 10^{9}$ ton $\mathrm{yr}^{-1}$, and the sediment mass of $3 \times 10^{18}$ ton give the sediment mean age of $3 \times 10^{18} / 7 \times 10^{9} \approx 430 \times 10^{6} \mathrm{yr}$. Because old recycled sediments are redeposited as new sediments, a total global sedimentation rate is $\mathrm{S}_{S}+\mathrm{S}_{c}=9 \times 10^{9}$ ton $\mathrm{yr}^{-1}$. It is instructive to compare this rate with other flux estimates. Global sedimentation in the oceans includes among others the following major contributions:

1. transport of dissolved materials by rivers and surface runoff to the oceans;

2. riverine transport of particulate materials from land;

3. sedimentation and burial of biogenic (mostly $\mathrm{CaCO}_{3}$, $\mathrm{SiO}_{2}$ and organic carbon taken as $\mathrm{CH}_{2} \mathrm{O}$ ) and inorganic mineral phases forming in ocean water and in oceanfloor sediments;

4. wind-transported dust; and

5. glacial ice-derived debris.

Rivers transport to the oceans between 2.78 and $4.43 \times 10^{9}$ ton $\mathrm{yr}^{-1}$ of dissolved materials derived from the chemical weathering of crystalline and sedimentary rocks (Garrels and Mackenzie, 1971; Drever, 1988; Berner and Berner, 1996). An estimated amount of particulate matter transported from land at present is much larger, 18,15 to 20 , and $20 \times 10^{9}$ ton $\mathrm{yr}^{-1}$ (Garrels and Mackenzie, 1971; Holland, 1978; Milliman and Syvitski, 1992; Berner and Berner, 1996). The suspended particle inflow is distributed unevenly over the ocean floor, where a major part of the input is deposited in the continental margins (about 80\%). The wind-blown dust deposition on the ocean has been variably estimated as $1.1 \pm 0.5 \times 10^{9}$ ton $\mathrm{yr}^{-1}$ (Goldberg, 1971), $0.06 \times 10^{9}$ ton $\mathrm{yr}^{-1}$ (Garrels and Mackenzie, 1971, p. 111), and global eolian dust deposition of 0.53 to $0.85 \times 10^{9}$ ton $\mathrm{yr}^{-1}$ (Prospero, 1981; Rea et al., 1994). Additionally, about $2 \times 10^{9}$ ton $\mathrm{yr}^{-1}$ enter the ocean as glacial ice debris (Garrels and Mackenzie, 1971). Present-day accumulation rates of $\mathrm{CaCO}_{3}$ and $\mathrm{SiO}_{2}$ on the sea floor amount to $3.2 \times 10^{9}$ ton $\mathrm{yr}^{-1}$ and $0.4 \times 10^{9}$ ton $\mathrm{yr}^{-1}$, respectively. The organic matter accumulation rate as $\mathrm{CH}_{2} \mathrm{O}$ is 0.5 ton $\mathrm{yr}^{-1}$. Thus these fluxes account for about $26 \times 10^{9}$ ton $\mathrm{yr}^{-1}$ of materials accumulating in the oceans; that is, more than the average accumulation rate of about $10 \times 10^{9}$ ton $\mathrm{yr}^{-1}$ for the past 1000 years (Wollast and 
Mackenzie, 1983; Chester, 2000). This shows that the ocean is not in steady state on the millennial time scale with respect to inputs and outputs of materials. In addition, the present rate of accumulation of solid sediments in the ocean by the five agents listed above is about three times higher than the average geologic rate of transfer (Garrels and Mackenzie, 1972; Garrels and Perry, 1974), probably reflecting the influence of relatively high continents of the present, the Pleistocene glaciation, and human land use changes.

As far as recycling of the ocean floor is concerned, the rate of new ocean floor formation at the spreading zones is $6.0 \pm 0.8 \times 10^{16} \mathrm{~g} \mathrm{yr}^{-1}$ or an area of $3.3 \pm 0.2 \mathrm{~km}^{2} \mathrm{yr}^{-1}$ (Mottl, 2003). The mass of the upper mantle down to the depth of $700 \mathrm{~km}$, representing $18.5 \%$ of the Earth mass, is $1,110 \times 10^{24} \mathrm{~g}(\mathrm{Li}, 2000)$. In a balanced system, the mass of oceanic crust subducted is the same as the newly formed crust, $6.0 \times 10^{16} \mathrm{~g} \mathrm{yr}^{-1}$. Some fraction of the total mass of oceanic sediments, $0.19 \times 10^{24} \mathrm{~g}(\mathrm{Li}, 2000)$, is also subducted with the oceanic crust and some fraction is incorporated in the continental margins. The rate of recycling of the ocean floor, $60 \times 10^{9}$ ton $\mathrm{yr}^{-1}$ as shown in Fig. 1, is the rate of oceanic crust subduction only.

The deep ocean is characterized by slow sedimentation rates of biogenic and hydrogenous materials produced in ocean water and detrital components from land, of an order of magnitude of millimeters per 1000 years. An upper bound of the sediment mass subducted with the ocean floor (Fig. 1) can be estimated from the rates of sedimentation and subduction, and the age of the subducted sediment. Mean unweighted sedimentation rates for different sections of the deep ocean are in the range of $3 \pm 1.5 \times 10^{-4} \mathrm{~cm} \mathrm{yr}^{-1}$ (Chester, 2000, p. 346). For the sediment age of $110 \pm 5 \times 10^{6}$ yr (Veizer, 1988) that enters the subduction zone with the underlying oceanic crustal plate, where $3.3 \mathrm{~km}^{2} \mathrm{yr}^{-1}$ of oceanic crust are subducted, an upper limit of the sediment subduction rate is:

Sediment subduction rate $\leq\left(3 \times 10^{-4} \mathrm{~cm} / \mathrm{yr}\right) \times 110 \times 10^{6} \mathrm{yr}$ $\times 3.3 \times 10^{10} \mathrm{~cm}^{2} \times 2 \mathrm{~g} / \mathrm{cm}^{3} \leq 2.2 \times 10^{9}$ ton $/ \mathrm{yr}$.

The preceding estimate is comparable to the sediment growth rate by crustal erosion (Fig. 1). For the sediment cycle to be balanced, the other three fluxes, shown by dashed arrows in Fig. 1, should have magnitudes assigned to them but these are not presently well enough known to do so.

\subsection{Mineral carbon geologic cycle and atmospheric $\mathrm{CO}_{2}$}

An example of the global cycle of calcium carbonate and silicate involves the Earth surface and upper mantle. The chemical reaction between calcium silicate and $\mathrm{CO}_{2}$ is a shorthand notation for the weathering of silicate rocks:

$\mathrm{CaSiO}_{3}+\mathrm{CO}_{2} \rightarrow \mathrm{CaCO}_{3}+\mathrm{SiO}_{2}$
In Eq. (1), $\mathrm{CaSiO}_{3}$ stands for calcium silicate minerals, of different stoichiometric proportions of $\mathrm{CaO}$ and $\mathrm{SiO}_{2}$ that occur in igneous, metamorphic, and sedimentary rocks reacting with $\mathrm{CO}_{2}$ and ultimately producing $\mathrm{CaCO}_{3}$ in water by such a reaction as:

$\mathrm{Ca}^{2+}+2 \mathrm{HCO}_{3}^{-}=\mathrm{CaCO}_{3}+\mathrm{CO}_{2}+\mathrm{H}_{2} \mathrm{O}$.

Subduction of $\mathrm{CaCO}_{3}$ accumulating on the ocean floor into the upper mantle can lead to breakdown of $\mathrm{CaCO}_{3}$ and release of $\mathrm{CO}_{2}$ and/or allow $\mathrm{CaCO}_{3}$ to react with $\mathrm{SiO}_{2}$ that represents silica in biogenic deep-ocean sediments and in the igneous melt or rocks:

$\mathrm{CaCO}_{3} \rightarrow \mathrm{CaO}+\mathrm{CO}_{2}$

$\mathrm{CaCO}_{3}+\mathrm{SiO}_{2} \rightarrow \mathrm{CaSiO}_{3}+\mathrm{CO}_{2}$

Reaction (4) is generally known as the Urey reaction, following Urey (1952, pp. 148 and ff.). According to Berner and Maasch (1996), the reaction and interpretation of its role in the global carbon cycle were introduced by J. J. Ebelmen much earlier, in 1845. Reaction (4) closes the carbonate and silicate cycle between the mantle and Earth surface cycle.

The actual environment where reactions of the nature of the Urey-Ebelman reaction take place is debatable. The original BLAG-type model (Berner et al., 1983; Lasaga et al., 1985 ) assumed these reactions took place during subduction according to Eq. (4), and the $\mathrm{CO}_{2}$ release rate was tied to the rate of plate accretion. Later work showed that $\mathrm{CO}_{2}$ generation reactions of this nature may take place during burial diagenesis and early metamorphism of sediments in thick sedimentary prisms, particularly with high geothermal gradients (Mackenzie and Pigott, 1981; Volk, 1989; Milliken, 2004; Berner, in press). An example of such a reaction is:

$$
\begin{aligned}
& 5 \mathrm{CaMg}\left(\mathrm{CO}_{3}\right)_{2}+\mathrm{Al}_{2} \mathrm{Si}_{2} \mathrm{O}_{5}(\mathrm{OH})_{4}+\mathrm{SiO}_{2}+2 \mathrm{H}_{2} \mathrm{O} \\
& \text { dolomite kaolinite silica } \\
& =\mathrm{Mg}_{5} \mathrm{Al}_{2} \mathrm{Si}_{3} \mathrm{O}_{10}(\mathrm{OH})_{8}+5 \mathrm{CaCO}_{3}+5 \mathrm{CO}_{2} \\
& \text { chlorite calcite }
\end{aligned}
$$

Reactions of this type or similar in sedimentary basins can lead to evolution of amounts of $\mathrm{CO}_{2}$ that equal or exceed those released from volcanic provinces (Kerrick et al., 1995; Milliken, 2004). In the Garrels and Mackenzie model (1972), these reactions were taken into account, but because their model was developed before extensive knowledge of basaltseawater reactions and associated fluxes, there is no provision in the model for the coupling of the exogenic system with the endogenic. Their sedimentary cycle was closed to exchange of materials between the mantle and crust.

The fact that large amounts of $\mathrm{CO}_{2}$ can be generated in sedimentary basins and eventually vented to the atmosphere potentially decouples $\mathrm{CO}_{2}$ production rates from plate generation rates. Thus the recent conclusion that plate accretion 
rates (and hence presumably $\mathrm{CO}_{2}$ generation rates associated with subduction) have not varied significantly for the last $180 \mathrm{Ma}$ (Rowley, 2002) may be completely compatible with the rise and fall of atmospheric $\mathrm{CO}_{2}$ concentrations during this period of time (e.g. Berner, 1991, 1994). The changes in atmospheric $\mathrm{CO}_{2}$ may be a consequence of processes operating mainly in the exogenic system: silicate mineral weathering as modified by the evolution and spread of land plants removing $\mathrm{CO}_{2}$ from the atmosphere, $\mathrm{CaCO}_{3}$ deposition and accumulation, diagenetic and metamorphic reactions in sedimentary piles returning some portion of the buried carbon as $\mathrm{CO}_{2}$ to the atmosphere, and the global imbalance between gross primary production and gross respiration leading to burial of organic matter in sediments and its later decomposition at subsurface depths and release of $\mathrm{CO}_{2}$. Indeed Arvidson et al. (2004), using a new Earth system model for the atmosphere-ocean-sediment system, have shown that the Phanerozoic changes in atmospheric $\mathrm{CO}_{2}$ as exhibited in the GEOCARB-type models (Berner, 1991, 1994; Berner and Kothavala, 2001) and confirmed to some extent by proxy data can be produced by processes operating mainly in the exogenic system without recourse to coupling of plate accretion rates with $\mathrm{CO}_{2}$ generation rates at subduction zones.

\subsection{Organic carbon geologic cycle and atmospheric $\mathrm{CO}_{2}$}

Carbon in biological primary production (mostly by photosynthesis in the presence of light and nutrient elements like $\mathrm{N}$ and $\mathrm{P}$ ) on land and in waters and the reverse process of respiration can be written in abbreviated form as:

$$
\begin{gathered}
\text { Photosynthesis (P) } \\
\mathrm{CO}_{2}+2 \mathrm{H}_{2} \mathrm{O} \rightleftarrows \mathrm{CH}_{2} \mathrm{O}+\mathrm{H}_{2} \mathrm{O}+\mathrm{O}_{2}
\end{gathered}
$$

Respiration (R)

or, in a shorter form,

Photosynthesis (P)

$$
\mathrm{CO}_{2}+\mathrm{H}_{2} \mathrm{O} \rightleftarrows \mathrm{CH}_{2} \mathrm{O}+\mathrm{O}_{2}
$$

Respiration (R)

The preceding reactions are also often written with all the reactants and products multiplied by 6 , giving the composition of organic matter as $\mathrm{C}_{6} \mathrm{H}_{12} \mathrm{O}_{6}$, analogous to the sugar glucose, or with the actual average stoichiometry of organic materials found in nature (e.g. marine plankton of molar ratio $\mathrm{C}: \mathrm{N}: \mathrm{P}$ of 106:16:1). Organic matter produced by photosynthesis stores about 470 to 490 kilojoules or 112 to 117 kilocalories of energy per 1 mole of carbon $(1 \mathrm{~mol} \mathrm{C}=12.011 \mathrm{~g} \mathrm{C}$; $1 \mathrm{kcal}=4.184 \mathrm{~kJ})$. When organic matter is oxidized, energy is released.

In photosynthesis, free molecular oxygen, $\mathrm{O}_{2}$, is produced from water. Respiration generally oxidizes less organic matter than has been produced by photosynthesis, which results in some $\mathrm{CH}_{2} \mathrm{O}$ and $\mathrm{O}_{2}$ left over, organic matter being stored in sediments and oxygen accumulating in the atmosphere: total Earth surface primary production $(\mathrm{P}$, mass of $\mathrm{C}$ fixed

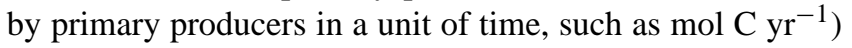
must have been greater than respiration ( $\mathrm{R}$, in the same units) on a geologically long time scale:

$\mathrm{P}-\mathrm{R}>0$.

This imbalance between photosynthesis and respiration has been of major importance to life on Earth because it enabled accumulation of molecular oxygen in the atmosphere and storage of organic matter in sediments over a period of perhaps at least the last 2 billion years or somewhat shorter than one-half of the Earth's age of 4.6 billion years. The net accumulation of $10.5 \times 10^{20} \mathrm{~mol}$ of organic carbon in sedimentary rocks (Table 1 ) has resulted in the accumulation of $0.38 \times 10^{20} \mathrm{~mol} \mathrm{O}_{2}$ in the present atmosphere. At first glance one would expect a one to one molar ratio between $\mathrm{O}_{2}$ accumulated and organic carbon buried; however, some of the $\mathrm{O}_{2}$ that was produced during geologic time has been used to oxidize other reduced substances on the Earth, such as ferrous iron, reduced sulfur, and reduced atmospheric gases such as methane.

It is likely that much of the total biomass of living and dead organic materials was established by the end of the Precambrian, near $545 \mathrm{Ma}$ ago, although biodiversity has continued to increase since then through the Phanerozoic (Wilson, 1990). Part of the reason for atmospheric $\mathrm{CO}_{2}$ and $\mathrm{O}_{2}$ fluctuations through Phanerozoic time (e.g. Berner, 1994; Berner and Canfield, 1989) is a result of the fact that on the geologic long-term time scale, the sum of the input of organic carbon to the ocean by primarily rivers and groundwater flow and production of organic carbon in the ocean must exceed aerobic and anaerobic respiration in the ocean in order for organic carbon to be buried. If there is an imbalance between the long-term flux of carbon related to organic carbon burial and its subsequent uplift, exposure to the atmosphere, and oxidation, both $\mathrm{CO}_{2}$ and $\mathrm{O}_{2}$ atmospheric concentrations will fluctuate. In the late Paleozoic, because of the increased burial of organic carbon in coal basins and the recalcitrance of the newly evolved land plant organic matter to decomposition, the net result was the depletion of $\mathrm{CO}_{2}$ and accumulation of $\mathrm{O}_{2}$ in the atmosphere (Berner and Canfield, 1989). Some feeling for the time scale of fluctuation can be obtained through a simple residence time calculation. The long-term burial flux of organic carbon in the ocean is equivalent to about $12 \times 10^{12} \mathrm{~mol} \mathrm{C} \mathrm{yr}^{-1}$. The pre-industrial mass of atmospheric $\mathrm{CO}_{2}$ was $5 \times 10^{16} \mathrm{~mol} \mathrm{C}$, at the $\mathrm{CO}_{2}$ concentration of 280 ppmv. If the burial flux of organic carbon were sustained and there were no feedback processes restoring atmospheric $\mathrm{CO}_{2}$, it would take only about 4200 years for the atmosphere to be depleted of $\mathrm{CO}_{2}$. The burial rate of $12 \times 10^{12} \mathrm{~mol} \mathrm{C}$ $\mathrm{yr}^{-1}$ is equivalent to the storage rate of a similar amount of $\mathrm{O}_{2}$ in the atmosphere. At today's atmospheric $\mathrm{O}_{2}$ mass of $0.38 \times 10^{20} \mathrm{~mol}$, atmospheric oxygen would double in 3.2 million years if there were no feedback mechanisms to re- 


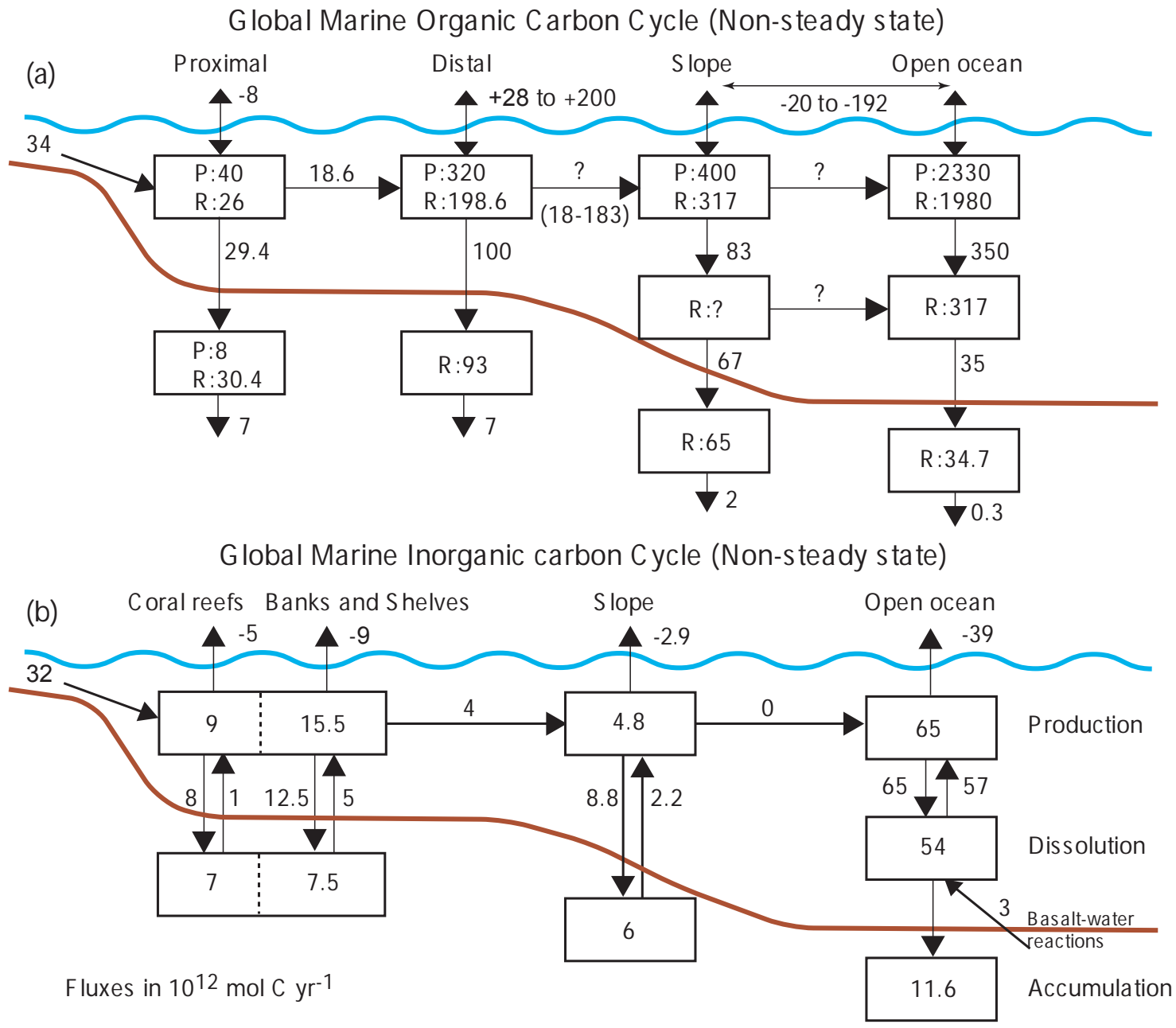

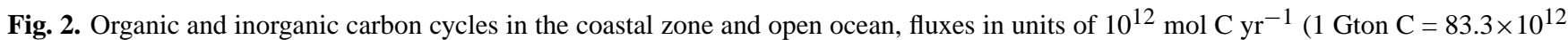
mol C; modified from Wollast, 1998; Rabouille et al., 2001; Wollast, 1994; Morse and Mackenzie, 1990; Milliman 1993). Both cycles are representations for the near present time and are not in steady state (they do not reflect atmospheric $\mathrm{CO}_{2}$ rise in industrial time and resulting $\mathrm{CO}_{2}$ transfer to the ocean). Less well-known fluxes are denoted by a question mark or a range in values. Air-sea exchange fluxes owing to the imbalance between gross primary production and total respiration of organic matter and precipitation of $\mathrm{CaCO}_{3}$ in the sub-domains of the ocean are also shown. The precipitation of $\mathrm{CaCO}_{3}$ always results in a flux of $\mathrm{CO}_{2}$ out of the ocean (negative value). The air-sea $\mathrm{CO}_{2}$ flux related to organic metabolism in the ocean or its sub-domains may be negative or positive depending on whether the region is a net source (net heterotrophic) or net sink (net autotrophic) of atmospheric $\mathrm{CO}_{2}$, respectively (see text). (a) Organic carbon cycle. P stands for net primary production (NPP), the net of gross primary production, GPP, less the respiration of the autotrophic plant community (autorespiration), Eq. (7), as commonly used in marine ecology. NPP is never negative (NPP $\geq 0$ ). R is remineralization of organic matter by consumer organisms (e.g. grazers and bacteria) in the water column and sediment by both aerobic and anaerobic processes. Riverine input of total organic carbon (dissolved and particulate), $34 \times 10^{12} \mathrm{~mol} / \mathrm{yr}$, includes an estimated $8 \times 10^{12} \mathrm{~mol} / \mathrm{yr}$ of non-reactive, refractory particulate organic carbon. (b) Inorganic carbon cycle showing the rates of $\mathrm{CaCO}_{3}$ production, dissolution, and net storage in sediments. The difference between the fluxes of precipitation of $\mathrm{CaCO}_{3}$ and its dissolution represents the net ecosystem calcification rate (NEC), Eq. (19). Riverine input of inorganic carbon, shown as $32 \times 10^{12} \mathrm{~mol} \mathrm{C} \mathrm{yr}^{-1}$, is less than that required to support the net accumulation rate of $32.1 \times 10^{12} \mathrm{~mol} \mathrm{C} \mathrm{yr}^{-1} \mathrm{because}$ of $\mathrm{CO}_{2}$ evasion to the atmosphere (see also Fig. 3).

move it from the atmosphere (e.g. weathering of fossil organic matter and reduced sulfur in uplifted rocks).

The geologic processes affecting the global cycle of carbon and atmospheric $\mathrm{CO}_{2}$ discussed above form the background for consideration of those aspects of the inorganic and organic carbon cycles in the modern ocean that give rise to air-sea exchange of $\mathrm{CO}_{2}$. The analysis in the subsequent sections will mainly focus on the shorter time scales and the imbalance between global marine gross primary production and total respiration, that is net ecosystem production (defined below), $\mathrm{CaCO}_{3}$ formation, and the air-ocean exchange of $\mathrm{CO}_{2}$ under the conditions of the increasing anthropogenic 


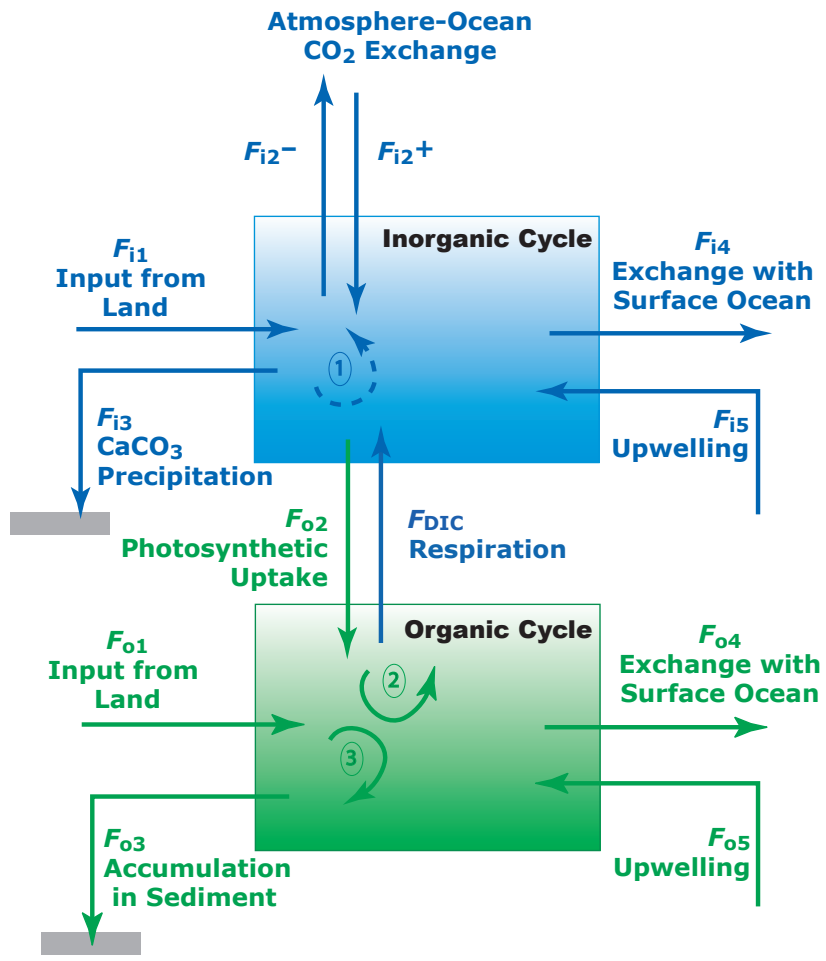

Fig. 3. Simplified two-box model of the coupled organic and inorganic carbon cycles in the coastal zone (from Mackenzie et al., 1998). The mass of carbon in the dissolved inorganic carbon reservoir (DIC) may change as a function of the inputs of DIC from land via rivers, surface runoff and groundwater flow, respiration and decay of organic matter, upwelling, air-sea exchange of $\mathrm{CO}_{2}$, precipitation of $\mathrm{CaCO}_{3}$, primary production, and physical exchange with the surface water of the open ocean. The organic carbon cycle is coupled to the inorganic carbon cycle via input of carbon from primary production and output due to remineralization of organic matter. Furthermore, the mass of total organic carbon in the organic reservoir may change due to inputs of both dissolved and particulate organic carbon form land, upwelling, accumulation of organic matter in sediments, and exchange with the open ocean. Curved arrow 1 indicates $\mathrm{CO}_{2}$ release by $\mathrm{CaCO}_{3}$ precipitation; curved arrows 2 and 3 indicate remineralization of organic carbon produced in situ and brought in from land that contributes to inorganic carbon production, $F_{\text {DIC }}$.

emissions of this gas to the atmosphere during the last 300 years of industrial time.

\section{Organic carbon balance in the global ocean}

The major driving force of the organic carbon cycle in the global ocean (Fig. 2a) is the production of organic matter by marine primary producers. Some of the estimates of global marine and terrestrial net primary production show that the oceans account for approximately $45 \%$ of the organic matter produced globally (Sect. 3). In most oceanic regions, primary production is limited by light intensity and the avail- ability of nutrients, mainly nitrogen and phosphorus, but in some areas by trace elements such as iron. The flux of carbon between the major reservoirs of the global marine organic carbon cycle is controlled by the magnitude of primary production, the extent of respiration and decay, and physical transport processes (Fig. 2a).

\subsection{Net ecosystem production}

The ecological concept of net ecosystem production (NEP) is the net change in organic carbon in an ecosystem over a period of time, usually one year. NEP in a system at steady state is the difference between the rates of gross primary production $(\mathrm{P})$ and total respiration $\left(\mathrm{R}_{\text {total }}\right)$; the latter is total ecosystem production of inorganic carbon by autotrophic and heterotrophic respiration, including aerobic respiration, decay, decomposition or remineralization (e.g. Smith and Mackenzie, 1987; Smith and Hollibaugh, 1993; Woodwell, 1995; Mackenzie et al., 1998):

$\mathrm{NEP}=\mathrm{P}-\mathrm{R}_{\text {total }}$.

Because NEP is the difference between two very large fluxes of gross primary production and total respiration, both of which are poorly known, it is very difficult to evaluate it from direct measurements.

A system at steady state is net heterotrophic when the amount of organic carbon respired, decayed, and decomposed is greater than the amount produced by gross photosynthesis: $\mathrm{NEP}<0$. A system is net autotrophic when the amount of carbon fixed by gross photosynthesis exceeds that remineralized by respiration: NEP $>0$. The net result is either a drawdown (net autotrophy) or evolution (net heterotrophy) of $\mathrm{CO}_{2}$ owing simply to organic metabolism in the ecosystem.

As mentioned above, a survey of estimates of rates of primary production and total respiration shows that $\mathrm{P}$ and $\mathrm{R}_{\text {total }}$ do not differ significantly one from another and the difference $\mathrm{P}-\mathrm{R}_{\text {total }}$ is practically indistinguishable from zero by evaluation of $\mathrm{P}$ and $\mathrm{R}_{\text {total }}$ individually. The oceanic coastal zone, of an areal extent of 7 to $10 \%$ of the ocean surface and a mean depth of about $130 \mathrm{~m}$ (e.g. Ver et al., 1999; Rabouille et al., 2001; Lerman et al., 2004) receives a large input of organic matter from land that is added to the organic matter produced in situ. For this budgetary reason, NEP of the oceanic coastal zone exerts a relatively greater control of the carbon cycle in this domain. From considerations of the material carbon balance (Fig. 3), NEP in the coastal ocean is derived from all sources and sinks of particulate and dissolved organic carbon, i.e. input from rivers, upwelling from intermediate oceanic waters, export to the open ocean, and burial in sediments. The material balance for the organic carbon reservoir in the coastal zone is (e.g. Smith and Hollibaugh, 1993; Mackenzie et al., 1998):

$\frac{d C_{\mathrm{org}}}{d t}=\left(F_{\mathrm{o} 1}+F_{\mathrm{o} 2}+F_{\mathrm{o} 5}\right)-\left(F_{\mathrm{o} 4}+F_{\mathrm{o} 3}+F_{\mathrm{DIC}}\right)\left(\mathrm{mol} \mathrm{yr}^{-1}\right)$, 
where $C_{\text {org }}$ is the mass of organic carbon in the reservoir and $t$ is time. Gross photosynthesis $\left(F_{\mathrm{o} 1}\right)$ and respiration and decay $\left(F_{\mathrm{DIC}}\right)$ are the linkages between the organic and inorganic carbon cycles. In a system near a steady state $\left(d C_{\mathrm{org}} / d t \approx 0\right)$, NEP can be defined as:

$\mathrm{NEP}=F_{\mathrm{o} 2}-F_{\mathrm{DIC}}=\left(F_{\mathrm{o} 3}+F_{\mathrm{o} 4}\right)-\left(F_{\mathrm{o} 1}+F_{\mathrm{o} 5}\right)$.

For a system in a transient state $\left(d C_{\text {org }} / d t \neq 0\right), \mathrm{NEP}^{*}$ can be defined as:

$\mathrm{NEP}^{*}=F_{\mathrm{o} 2}-F_{\mathrm{DIC}}=\left.\Delta C_{\mathrm{org}}\right|_{t}+\left(F_{\mathrm{o} 3}+F_{04}\right)-\left(F_{\mathrm{o} 1}+F_{\mathrm{o} 5}\right)$,

where the difference between $\mathrm{NEP}^{*}$ and NEP is $\Delta C_{\text {org }}$, the accumulation or loss of organic carbon in the reservoir in a unit time. While NEP* and NEP can be negative, zero or positive, NEP* can theoretically be positive if NEP is negative. NEP* is essentially equivalent to the term for nonsteady state net biome production (NBP) as used by terrestrial ecologists for changes in the size of the terrestrial carbon pool and thus non-zero NBP. Equations (10) and (11) describe NEP as the net sum of the accumulation and reduction in organic carbon mass and the import and export fluxes of organic carbon in the coastal zone. Equation (9) states that organic carbon accumulates in the coastal zone when the inputs are greater than the outputs. Equation (10) gives the balance of organic carbon only, and if there is more organic carbon imported into the coastal zone than removed by export (i.e. the inputs $F_{\mathrm{o} 1}+F_{\mathrm{o} 5}$ are relatively large), then the excess of input would be remineralized and leave the organic carbon pool as DIC in the flux $F_{\text {DIC. These equations show }}$ that in a system that is net autotrophic $\left(\mathrm{NEP}^{*}>0\right)$, relatively higher rates of primary production $\left(F_{\mathrm{o} 2}\right)$ can give rise to a higher storage rate of organic carbon $\left(F_{\mathrm{o} 3}\right.$ and/or $\left.\Delta C_{\mathrm{org}}\right)$, if export to the open ocean $\left(F_{\mathrm{O} 4}\right)$ is smaller than the other removal fluxes $\left(F_{\mathrm{o} 3}\right)$, which is in agreement with observations that primary production in oceanic surface waters may control to some extent the rate of deposition of organic carbon initially reaching the ocean floor (Lee, 1992; Müller and Suess, 1979). An important conclusion is that the export flux of organic carbon $\left(F_{\mathrm{O} 4}\right)$, whose magnitude is related to the rate of water movement and the mass of dissolved and particulate organic carbon available for transport to the open ocean, also determines the trophic state (NEP*) of the coastal zone.

It should be emphasized that we employ $\mathrm{NEP}^{*}$ in the following model calculations for the coastal zone because there is no a priori reason to assume that the coastal zone organic carbon cycle is in steady state when viewed on the time scale of decades to centuries. Indeed short time scale, direct observations of $\mathrm{P}$ and $\mathrm{R}$ may be misleading in terms of interpretation of the trophic status of a system that is evolving with time. In addition, because we know that dissolved organic carbon (DOC) in the ocean has a mean age of about 1000 years (Bauer et al., 1992) and is being stored in certain regions of the ocean (Church et al., 2002), it is unlikely that the organic carbon cycle in the ocean is in a steady state, al- though whether the situation is a long-term or transient phenomenon is unknown.

\subsection{Estimates of the organic carbon balance}

Several investigators have made reasonable estimates of the net global exchange of $\mathrm{CO}_{2}$ between the ocean and the atmosphere due to organic metabolism for the pre-anthropogenic global ocean, calculated from the small difference between the large biogeochemical fluxes of gross primary production and total ecosystem autotrophic and heterotrophic respiration. Because these earlier estimates shared common sources of data for the biogeochemical flux components used in the calculations, it is not surprising that the earlier estimates agreed well with each other in both the magnitude and direction of the net flux of carbon. Estimation of net ecosystem production in a transient-state system $\left(\mathrm{NEP}^{*}\right)$ requires knowledge of the rate of organic carbon change, $\Delta C_{\text {org }}$ in Eq. (11), that is not usually available. Therefore the estimates of net ecosystem production discussed below refer to NEP, as given in Eq. (10). Garrels and Mackenzie (1972) estimated that the global ocean was a net source of $\mathrm{CO}_{2}$ to the atmosphere in pristine time at the rate of $-27 \times 10^{12}$ moles

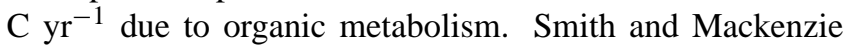
(1987) concluded that because of aerobic and anaerobic respiration and remineralization of organic carbon exceeding in situ gross photosynthesis, the pre-industrial global ocean was a net heterotrophic system, hence a source of $\mathrm{CO}_{2}$ with a calculated flux of $-21 \times 10^{12} \mathrm{~mol} \mathrm{C} \mathrm{yr}^{1}$. Organic carbon transported from land via rivers and remineralization of a portion of that carbon in the ocean fueled in part the heterotrophy of the global ocean. Calculations by Wollast and Mackenzie (1989) and Smith and Hollibaugh (1993) based on biogeochemical processes involving organic carbon showed a net

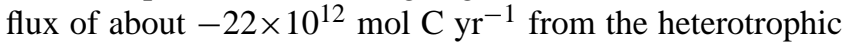
ocean to the atmosphere. Williams and Bower (1999) calculated from Duarte and Agusti's data (1998) on bacterial respiration and net primary production that the oceanic surface layer should be net heterotrophic by as much as $-500 \times 10^{12}$ mol $\mathrm{C} \mathrm{yr}^{-1}$, a result disputed by the four authors themselves but defended by Duarte et al. (1999). More recently, Ducklow and McAllister (2004) concluded that the open ocean over the entire water column is heterotrophic by $-200 \times 10^{12}$ mol $\mathrm{C} \mathrm{yr}^{-1}$.

There have only been a few attempts to estimate either the long-term or present-day NEP of the coastal ocean separately from that of the open ocean. One of the primary reasons is that the transfer fluxes between the coastal margin and the open ocean are poorly constrained (Gattuso et al., 1998). Additionally, it is difficult to model the coastal oceanic region separately from the open ocean because of its large spatial and temporal variability (Mantoura et al., 1991). Furthermore, there may be differences between the proximal and distal parts of the coastal zone: the proximal part (surface area: $1.8 \times 10^{12} \mathrm{~m}^{2}$ ) represents the bays, la- 
goons, estuaries, deltas, and marine wetlands and the distal (surface area: $27 \times 10^{12} \mathrm{~m}^{2}$ ) includes the continental shelves (Fig. 2a). Despite these difficulties, two of the most notable and frequently cited estimates of coastal ocean NEP (Smith and Hollibaugh, 1993; Wollast and Mackenzie, 1989) independently concluded that the coastal ocean was net heterotrophic in pre-industrial times. Wollast and Mackenzie's (1989) estimated heterotrophy in the global ocean included a coastal ocean that was heterotrophic at the rate of $-3.3 \times 10^{12}$ moles $\mathrm{C} \mathrm{yr}^{-1}$. Smith and Hollibaugh (1993; Smith, 1995) also calculated the coastal zone to be net heterotrophic at the rate of $-7 \times 10^{12}$ moles $\mathrm{C} \mathrm{yr}^{-1}$. Pre-industrial coastal zone heterotrophy was estimated at $-8 \times 10^{12}$ moles $\mathrm{C} \mathrm{yr}^{-1}$ by Mackenzie et al. (1998) from the long-term rates of primary production, respiration, net metabolism, river loading of organic carbon, organic carbon burial, and chemical reactivity of terrestrial organic matter. Gattuso et al. (1998) estimated that the present-day continental shelves have a positive metabolic balance, such that NEP is equivalent to $+68 \times 10^{12}$ mol $\mathrm{yr}^{-1}$. They further estimated that estuarine net ecosys-

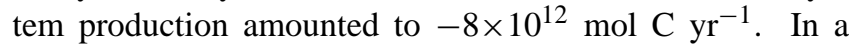
global model developed for the coastal ocean of the interactive biogeochemical cycles of $\mathrm{C}, \mathrm{N}$, and $\mathrm{O}$, Rabouille et al. (2001) estimated that the pre-anthropogenic nearshore (proximal) coastal zone of the ocean was net heterotrophic by $-8.4 \times 10^{12} \mathrm{~mol} \mathrm{C} \mathrm{yr}^{-1}$ and that the pre-anthropogenic distal continental shelf was net autotrophic by $+28.4 \times 10^{12}$ mol C $\mathrm{yr}^{-1}$. Finally, Ducklow and McCallister (2004) estimated recently that the present-day global coastal ocean is net autotrophic based on estimates of inputs and outputs of

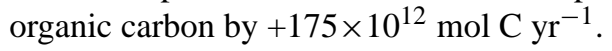

In conclusion it appears that the present-day proximal coastal zone is net heterotrophic by a small amount, the distal continental shelf net autotrophic, the degree to which is controversial, and the open ocean over its whole depth significantly heterotrophic. The past NEP of the coastal zone is still a matter of conjecture but in Sect. 6.3, we adopt for modeling purposes a pre-industrial coastal ocean that is slightly heterotrophic throughout its extent and explain the implications of doing so.

\section{The inorganic carbon cycle in the global ocean}

The shallow-water marine inorganic carbon cycle constitutes a significant part of the global marine inorganic carbon cycle (Fig. 2b). Approximately $25 \%$ of calcium carbonate produced globally is produced within the global coastal ocean and almost $50 \%$ of calcium carbonate that accumulates in global marine sediments accumulates within this region (Fig. 2b) because of some dissolution of deep-sea carbonates (Milliman, 1993; Wollast, 1994, 1998). About half of this accumulation is in regions of coral reefs. According to Milliman (1993), accumulation of calcium carbonate minerals in the coastal ocean is currently unusually high owing to the significant rise in sea level since the Last Glacial Maximum $18000 \mathrm{yr}$ ago and the subsequent expansion of shallowwater depositional environments. Thus, the global marine inorganic carbon cycle currently may be in a non-steady state, where more calcium carbonate is deposited in marine sediments than is added to the ocean via river input and basaltseawater interactions (Fig. 2b). In the pre-industrial world, release of $\mathrm{CO}_{2}$ from the oceans to the atmosphere due to $\mathrm{CaCO}_{3}$ deposition is necessary to balance that $\mathrm{CO}_{2}$ consumed by the weathering of carbonates. The non-steady state condition may have been responsible for some of the rise in atmospheric $\mathrm{CO}_{2}$ since the last glacial maximum to pre-industrial time as $\mathrm{CaCO}_{3}$ accumulated in shallow-water environments during the sea level rise and $\mathrm{CO}_{2}$ was vented to the atmosphere. This conclusion is still a matter of debate (e.g. Berger, 1982; Keir and Berger, 1985; Milliman, 1993; Opdyke and Walker, 1992; Walker and Opdyke, 1995; Broecker and Henderson, 1998).

The marine inorganic carbon cycle is strongly coupled to the marine organic carbon cycle through primary production and remineralization of organic matter (Fig. 3). Consequently, direct alterations to either one of these cycles owing to natural or anthropogenic factors are likely to affect the other.

From experimental evidence and geochemical modeling, it has been suggested that the saturation state of surface ocean waters with respect to carbonate minerals will decline during the twenty-first century owing to increased invasion of atmospheric $\mathrm{CO}_{2}$ (e.g. Andersson et al., 2003; Kleypas et al., 1999; Mackenzie et al., 2000). The degree of supersaturation of surface ocean water with respect to calcite has decreased 15 to $19 \%$ as a result of atmospheric $\mathrm{CO}_{2}$ rise from $280 \mathrm{ppmv}$ in pre-industrial time to $370 \mathrm{ppmv}$ in the present (Sect. 6.1). Although data are sparse globally, monthly observations from the Hawaii Ocean Time series station (HOT, located in the North Pacific subtropical gyre) between 1988 and 2000 indicate a consistent annual trend of increasing surface water total DIC and decreasing carbonate saturation state (Hawaii Ocean Time series, 2003; Winn et al., 1998; Andersson, 2003). This situation has also been observed in other regions of the ocean (e.g. Chung et el., 2004).

Decreasing surface water carbonate saturation state could negatively affect the ability of calcareous organisms, such as corals, coralline algae, coccolithophorids, and other taxa, to produce skeletons, shells, and tests out of calcium carbonate and it may result in calcareous organisms and structures being weaker and more vulnerable to environmental stress and erosion. Consequently, the role and function of calcareous ecosystems and communities may be altered as a result of future changing environmental conditions (Gattuso et al., 1999; Kleypas et al., 1999, 2001; Riebesell et al., 2000; Langdon et al., 2000; Mackenzie et al., 2000; Leclercq et al., 2000, 2002; Andersson et al., 2003).

At present, calcium carbonate is almost exclusively produced by calcareous organisms and only minor quantities are 
produced abiotically as cements within sediments or precipitated as whitings from the water column (e.g. Morse and Mackenzie, 1990; Milliman, 1993; Wollast, 1994; IglesiasRodriguez et al., 2002). Decreased carbonate saturation state and consequent decreased production of calcium carbonate may significantly alter the global marine inorganic carbon cycle and also affect the marine organic carbon cycle. Decreased calcification also implies a decreased flux of $\mathrm{CO}_{2}$ to the atmosphere owing to this process (Ware et al., 1992; Frankignoulle et al., 1994) and could act as a negative feedback to increasing atmospheric $\mathrm{CO}_{2}$ (Zondervan et al., 2001). However, the magnitude of this feedback is insignificant relative to the total invasion of anthropogenic $\mathrm{CO}_{2}$ into the surface ocean, as discussed in more detail in Sect. 6.

Ultimately, decreasing surface and pore water carbonate saturation state may cause increased dissolution of carbonate minerals in the water column and within the pore water-sediment system. Such dissolution, in particular of metastable carbonate minerals such as high-magnesian calcite, that is unstable relative to calcite, could act as a buffer to neutralize anthropogenic $\mathrm{CO}_{2}$ and prevent at least some of the negative effects on calcareous organisms and ecosystems (Garrels and Mackenzie, 1981; Barnes and Cuff, 2000; Halley and Yates, 2000). Indeed it has been suggested that the rate of carbonate dissolution might equal the rate of calcification once atmospheric $\mathrm{CO}_{2}$ concentration reached double pre-industrial levels and buffer the surface water from rising atmospheric $\mathrm{CO}_{2}$ levels (Halley and Yates, 2000). However, recent model results indicate that such dissolution will not produce sufficient alkalinity and anthropogenically-induced changes in coastal ocean saturation state will not be restored by the dissolution of metastable carbonate minerals (Andersson et al., 2003). Thus, most investigators believe that calcification by calcareous marine organisms and the development of carbonate reefs could be negatively affected as a consequence of rising anthropogenic $\mathrm{CO}_{2}$ and lowering of the saturation state of seawater with respect to carbonate minerals (Gattuso et al., 1999; Kleypas et al., 1999; Mackenzie et al., 2000; Langdon et al., 2000; Leclercq et al., 2002).

During early diagenetic modifications on the seafloor, dissolution of carbonate minerals follows a sequence based on mineral thermodynamic stability, progressively leading to removal of the more soluble phases until the stable phases remain (Schmalz and Chave, 1963; Neumann, 1965; Wollast et al., 1980). Thus increased dissolution of carbonate minerals owing to anthropogenically-induced changes in carbonate saturation state of the coastal ocean can potentially affect the average $\mathrm{CaCO}_{3}$ composition (its $\mathrm{Mg}$ content) and rates of precipitation of carbonate cements in contemporary shallow-water marine sediments (Andersson et al., 2003). It should be pointed out that the extent of carbonate dissolution is mainly controlled by microbial remineralization of organic matter producing $\mathrm{CO}_{2}$ rather than the carbonate reaction kinetics (Morse and Mackenzie, 1990). Increased transport and deposition of organic matter to the sediments of the coastal

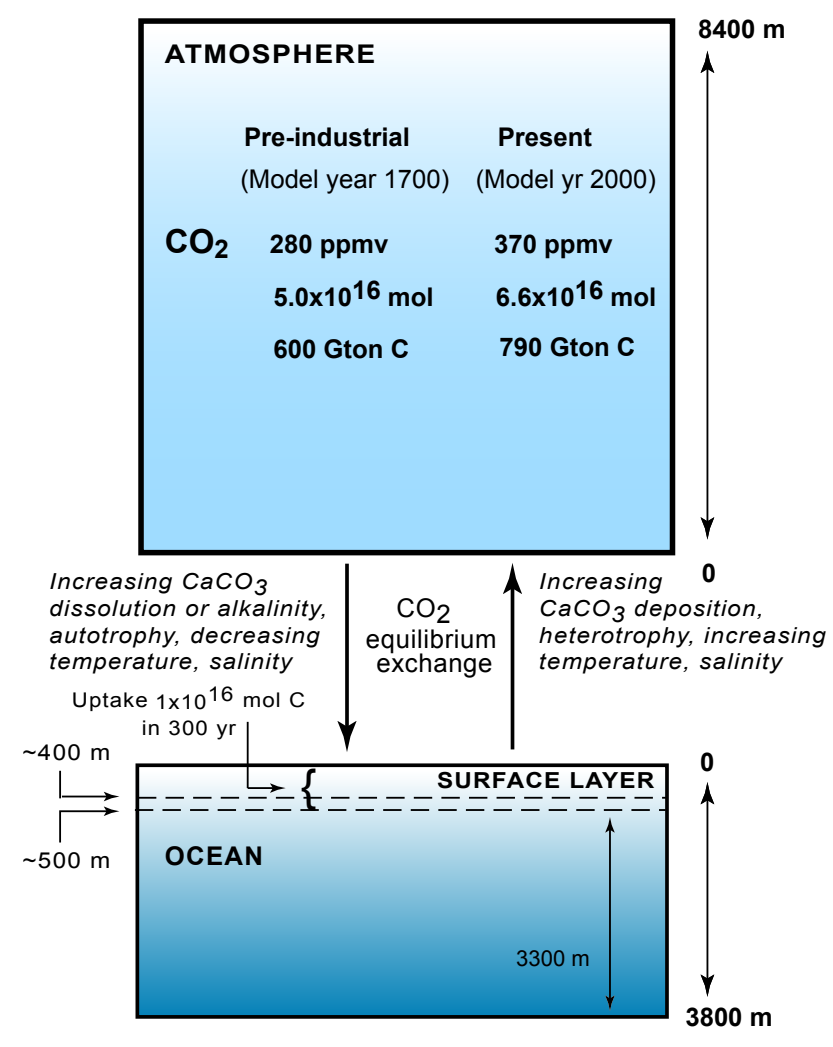

Fig. 4. Carbon changes in the atmosphere and surface ocean in the last 300 years of industrial time. Thicknesses of the two reservoirs (8400 and $3800 \mathrm{~m}$ ) shown approximately to scale. Processes that affect the direction of $\mathrm{CO}_{2}$ exchange between the atmosphere and surface ocean are indicated next to the flux arrows. Thickness of surface ocean layer, 400 to $500 \mathrm{~m}$, that is equilibrated with atmospheric $\mathrm{CO}_{2}$ is explained in the text.

zone (Mackenzie et al., 1993; Meybeck, 1982) and/or subsequent changes in the NEP* could therefore have an important effect on the carbonate content and composition of marine sediments.

\section{Rising atmospheric $\mathrm{CO}_{2}$ and air-sea exchange of $\mathrm{CO}_{2}$}

Net increase in atmospheric $\mathrm{CO}_{2}$ due to fossil fuel burning and land-use changes was from $280 \mathrm{ppmv}^{\mathrm{CO}} \mathrm{C}_{2}$ to $370 \mathrm{ppmv}$ by the end of the 20th century. Total $\mathrm{CO}_{2}$ addition to the atmosphere by the year 2000 has been estimated at 461 \pm 19 Gton $\mathrm{C}\left(3.84 \times 10^{16} \mathrm{~mol} \mathrm{C}\right)$, of which $134 \pm 6$ Gton $\left(1.12 \times 10^{16} \mathrm{~mol}\right)$ were taken up by land ecosystems, leaving $327 \pm 13$ Gton $\left(2.72 \times 10^{16} \mathrm{~mol}\right)$ to be distributed between the atmosphere and the ocean. Of these, an estimated $122 \pm 2$ Gton $\mathrm{C}\left(1.02 \times 10^{16} \mathrm{~mol}\right)$ were transferred to the ocean, leaving $205 \pm 13$ Gton $\mathrm{C}\left(1.71 \times 10^{16} \mathrm{~mol}\right)$ in the atmosphere (Ver et al., 1999; Mackenzie et al., 2001; see also Sarmiento et al., 1992; Hudson et al., 1994; Bruno and Joos, 1997). 
Table 2. Changes in dissolved carbon species, $\mathrm{pH}$, and degree of saturation with respect to calcite $(\Omega)$ from an increase in atmospheric $\mathrm{CO}_{2}$ from 280 to $370 \mathrm{ppmv}$, at constant total alkalinity $\mathrm{A}_{T}=2.544 \times 10^{-3} \mathrm{~mol} / \mathrm{kg}$, at 25 and $5^{\circ} \mathrm{C}$.

\begin{tabular}{cccccccc}
\hline Temperature & $P_{\mathrm{CO}_{2}}(\mathrm{bar})$ & $\mathrm{A}_{C}(\mathrm{~mol} / \mathrm{kg})$ & {$\left[\mathrm{CO}_{2}\right](\mathrm{mol} / \mathrm{kg})$} & $\mathrm{pH}$ & {$[\mathrm{DIC}](\mathrm{mol} / \mathrm{kg})$} & {$\left[\mathrm{CO}_{3}^{2-}\right](\mathrm{mol} / \mathrm{kg})$} & $\Omega$ \\
\hline \multirow{2}{*}{$25^{\circ} \mathrm{C}$} & $2.8 \times 10^{-4}$ & $2.415 \times 10^{-3}$ & $7.95 \times 10^{-6}$ & 8.200 & $2.092 \times 10^{-3}$ & $3.305 \times 10^{-4}$ & 7.95 \\
& $3.7 \times 10^{-4}$ & $2.435 \times 10^{-3}$ & $10.50 \times 10^{-6}$ & 8.106 & $2.162 \times 10^{-3}$ & $2.835 \times 10^{-4}$ & 6.82 \\
\hline \multirow{2}{*}{$5^{\circ} \mathrm{C}$} & $2.8 \times 10^{-4}$ & $2.464 \times 10^{-3}$ & $14.60 \times 10^{-6}$ & 8.213 & $2.300 \times 10^{-3}$ & $1.786 \times 10^{-4}$ & 4.26 \\
& $3.7 \times 10^{-4}$ & $2.478 \times 10^{-3}$ & $19.29 \times 10^{-6}$ & 8.108 & $2.352 \times 10^{-3}$ & $1.456 \times 10^{-4}$ & 3.47 \\
\hline
\end{tabular}

We address three questions based on modeling calculations of the carbon cycle related to the increase in atmospheric $\mathrm{CO}_{2}$ during industrial time of the past 300 years:

1. What were the changes in the ocean-water carbonate system due to the increase in atmospheric $\mathrm{CO}_{2}$ ?

2. What was the thickness of the surface ocean layer that absorbed the increased $\mathrm{CO}_{2}$ ?

3. What has been the history of the $\mathrm{CO}_{2}$ exchange flux between the shallow-ocean environment and the atmosphere?

The inorganic carbon balance in the atmosphere and ocean, with their thicknesses drawn to scale in Fig. 4, shows an increase in atmospheric $\mathrm{CO}_{2}$ during the industrial period of 300 years and uptake of $\mathrm{CO}_{2}$ by the surface ocean layer, as will be discussed in more detail later in this section. In Fig. 4 are also shown the main inorganic and organic processes that can be responsible for the direction of $\mathrm{CO}_{2}$ flow between the ocean and atmosphere: the previously discussed role of heterotrophic respiration and $\mathrm{CaCO}_{3}$ precipitation in producing excess $\mathrm{CO}_{2}$ in water and its subsequent transfer to the atmosphere; conversely, transfer of $\mathrm{CO}_{2}$ from the atmosphere to surface water by an increasing autotrophic production or its increasing alkalinity and/or $\mathrm{CaCO}_{3}$ dissolution; and the effects on the direction of transfer due to the dependence of $\mathrm{CO}_{2}$ solubility on temperature and salinity.

\subsection{Air and surface ocean system}

The simplest approximation to the distribution of $\mathrm{CO}_{2}$ between the atmosphere and surface ocean water is a solubility equilibrium at a certain temperature:

$K_{0}^{\prime}=\frac{\left[\mathrm{CO}_{2}\right]}{P_{\mathrm{CO}_{2}}}$

where $\left[\mathrm{CO}_{2}\right]$ is concentration of dissolved $\mathrm{CO}_{2}$ species $(\mathrm{mol} / \mathrm{kg}), P_{\mathrm{CO}_{2}}$ is atmospheric partial pressure of $\mathrm{CO}_{2}$ (bar) at equilibrium with solution, and $K_{0}^{\prime}$ is the temperaturedependent solubility coefficient $\left(\mathrm{mol} \mathrm{kg}^{-1} \mathrm{bar}^{-1}\right)$. The concept of a chemical equilibrium is only an approximation to the atmosphere in contact with surface ocean water because of several factors: ocean surface temperature varies with latitude and $\mathrm{CO}_{2}$ solubility increases at lower temperatures and lower salinities; oceanic sections of deeper water upwelling are often sources of $\mathrm{CO}_{2}$ emissions to the atmosphere, whereas the downwelling areas, such as the North Atlantic, are sinks of atmospheric $\mathrm{CO}_{2}$ transporting it into the deeper waters; and global balance of directions of $\mathrm{CO}_{2}$ flows across the ocean-air interface shows large parts of the Northern and Southern hemispheres as $\mathrm{CO}_{2}$ sinks and regions in the lower, warmer latitudes as sources (Takahashi, 1989; Chester, 2000). In general, as has also been discussed in the preceding sections, mineralization or oxidation of organic matter brought from land to the surface ocean is a source of additional $\mathrm{CO}_{2}$ in ocean water; deposition of $\mathrm{CaCO}_{3}$ by inorganic or biological processes releases $\mathrm{CO}_{2}$ into ocean water; and primary production in surface waters, consuming dissolved $\mathrm{CO}_{2}$, may create at least temporarily a disequilibrium between the atmosphere and ocean water.

For a rise in atmospheric $P_{\mathrm{CO}_{2}}$ from 280 to 370 ppmv, dissolved $\left[\mathrm{CO}_{2}\right]$ concentration also increases and, as shown in Table 2 , the increase at $5^{\circ} \mathrm{C}$ is greater than at $25^{\circ} \mathrm{C}$ because of the higher solubility of $\mathrm{CO}_{2}$ at lower temperatures. The higher concentration of dissolved $\mathrm{CO}_{2}$ would result in an increase in total dissolved inorganic carbon (DIC), changes in the $\left[\mathrm{H}^{+}\right]$-ion concentration, and changes in the concentrations of the individual dissolved carbonate species $\left[\mathrm{HCO}_{3}^{-}\right]$, $\left[\mathrm{CO}_{3}^{2-}\right]$, and $\left[\mathrm{CO}_{2}\right]$. Assuming that during the period of $\leq 300$ years, the total alkalinity $\left(\mathrm{A}_{T}\right)$ of surface ocean water remained constant (that is, no significant amounts of carbonate precipitation or dissolution or addition of alkalinity from land are considered), the new values of ocean water $\mathrm{pH}$ and DIC at the higher atmospheric $P_{\mathrm{CO}_{2}}$ are given in Table 2. The calculation is based on the relationships discussed below.

The values of total alkalinity, $\mathrm{A}_{T}$, and concentration of dissolved inorganic carbon (DIC) are defined by the following relationships:

$$
\begin{aligned}
& \mathrm{A}_{T}=\mathrm{A}_{C}+\mathrm{A}_{B}+\mathrm{A}_{w}(\mathrm{~mol} / \mathrm{kg}) \\
& A_{T}=\frac{\left[\mathrm{CO}_{2}\right] K_{1}^{\prime}}{\left[\mathrm{H}^{+}\right]}\left(1+\frac{2 K_{2}^{\prime}}{\left[\mathrm{H}^{+}\right]}\right)+\frac{B_{T}}{1+\left[\mathrm{H}^{+}\right] / K_{B}^{\prime}}+\frac{K_{w}^{\prime}}{\left[\mathrm{H}^{+}\right]}-\left[\mathrm{H}^{+}\right],
\end{aligned}
$$


Table 3. Apparent dissociation constants at ocean water salinity of 35, calculated from the equations of Mucci (1983) and other sources, as summarized in Zeebe and Wolf-Gladrow (2001).

\begin{tabular}{lcc}
\hline Parameter & at $25^{\circ} \mathrm{C}$ & at $5^{\circ} \mathrm{C}$ \\
\hline$K_{0}^{\prime}=\left[\mathrm{CO}_{2}\right] / P_{\mathrm{CO}_{2}}$ & $2.839 \times 10^{-2}$ & $5.213 \times 10^{-2}$ \\
$K_{1}^{\prime}=\left[\mathrm{H}^{+}\right]\left[\mathrm{HCO}_{3}^{-}\right] /\left[\mathrm{CO}_{2}\right]$ & $1.392 \times 10^{-6}$ & $8.838 \times 10^{-7}$ \\
$K_{2}^{\prime}=\left[\mathrm{H}^{+}\right]\left[\mathrm{CO}_{3}^{2-}\right] /\left[\mathrm{HCO}_{3}^{-}\right]$ & $1.189 \times 10^{-9}$ & $5.191 \times 10^{-10}$ \\
$K_{B}^{\prime}=\left[\mathrm{H}^{+}\right]\left[\mathrm{B}(\mathrm{OH})_{4}^{-}\right] /\left[\mathrm{B}(\mathrm{OH})_{3}\right]$ & $2.527 \times 10^{-9}$ & $1.431 \times 10^{-9}$ \\
$K_{w}^{\prime}=\left[\mathrm{H}^{+}\right]\left[\mathrm{OH}^{-}\right]$ & $6.063 \times 10^{-14}$ & $8.549 \times 10^{-15}$ \\
$K_{\mathrm{cal}}^{\prime}=\left[\mathrm{Ca}^{2+}\right]\left[\mathrm{CO}_{3}^{2-}\right]$ & $4.273 \times 10^{-7}$ & $4.309 \times 10^{-7}$ \\
$B_{T}(\mathrm{~mol} / \mathrm{kg})$ & $4.160 \times 10^{-4}$ & $4.160 \times 10^{-4}$ \\
\hline
\end{tabular}

where $A_{C}$ is carbonate alkalinity, also represented by the first term on the right-hand side of Eq. (14); $A_{B}$ is borate alkalinity, as in the second term in Eq. (14), where $B_{T}$ is total boron concentration in ocean water; $\mathrm{A}_{w}$ is water or hydrogen alkalinity, represented by the last two terms in Eq. (14); and the definitions and values of the apparent dissociation constants, $K^{\prime}$, are given in Table 3 .

$$
\begin{aligned}
{[\mathrm{DIC}] } & =\left[\mathrm{CO}_{2}\right]+\left[\mathrm{HCO}_{3}^{-}\right]+\left[\mathrm{CO}_{3}^{2-}\right] \\
& =P_{\mathrm{CO}_{2}} K_{0}^{\prime}\left(1+\frac{K_{1}^{\prime}}{\left[\mathrm{H}^{+}\right]}+\frac{K_{1}^{\prime} K_{2}^{\prime}}{\left[\mathrm{H}^{+}\right]^{2}}\right)(\mathrm{mol} / \mathrm{kg}) .
\end{aligned}
$$

In this model of $\mathrm{CO}_{2}$ uptake from the atmosphere at an equilibrium with a surface ocean layer, the initial atmospheric $\mathrm{CO}_{2}$ of $280 \mathrm{ppmv}$ and an assumed $\mathrm{pH}=8.20$ at $25^{\circ} \mathrm{C}$ give total alkalinity $\mathrm{A}_{T}=2.544 \times 10^{-3} \mathrm{~mol} / \mathrm{kg}$ that we consider constant. At other combinations of temperature and atmospheric $P_{\mathrm{CO}_{2}}$, the hydrogen-ion concentration, $\left[\mathrm{H}^{+}\right]$, is obtained by solution of Eq. (14) and new DIC concentration computed from Eq. (15). At these conditions, carbonate alkalinity $\left(\mathrm{A}_{C}\right)$ accounts for a major part, 95 to $97 \%$, of total alkalinity $\left(\mathrm{A}_{T}\right)$. To estimate the degree of saturation of ocean water with respect to calcite, the carbonate-ion concentration that depends on $\mathrm{P}_{\mathrm{CO}_{2}}$ and $\left[\mathrm{H}^{+}\right]$,

$\left[\mathrm{CO}_{3}^{2-}\right]=\frac{\left[\mathrm{CO}_{2}\right] K_{1}^{\prime} K_{2}^{\prime}}{\left[\mathrm{H}^{+}\right]^{2}}(\mathrm{~mol} / \mathrm{kg})$

and constant calcium-ion concentration of $\left[\mathrm{Ca}^{2+}\right]=$ $1.028 \times 10^{-2} \mathrm{~mol} / \mathrm{kg}$ are used in

$\Omega=\frac{\left[\mathrm{Ca}^{2+}\right]\left[\mathrm{CO}_{3}^{2-}\right]}{K_{\text {cal }}^{\prime}}$

the results of which are also given in Table 2 for the preindustrial and present-day conditions.

\subsection{Industrial $\mathrm{CO}_{2}$ surface ocean layer}

An increase in atmospheric $\mathrm{CO}_{2}$ from the pre-industrial value of $280 \mathrm{ppmv}$ to $370 \mathrm{ppmv}$ in the present results in an increase of DIC by 2.6 to $1.7 \%$, lowering of the $\mathrm{pH}$ by about 0.1 unit, and a decrease in the $\left[\mathrm{CO}_{3}^{2-}\right]$-ion concentration (Table 2). The latter is responsible for the lowering of the degree of supersaturation of surface ocean water with respect to calcite, both at 25 and $5^{\circ} \mathrm{C}$. It should be noted that the increase in DIC represents the total mass of carbon transferred from the atmosphere as $\mathrm{CO}_{2}$ to ocean water, where the added $\mathrm{CO}_{2}$ causes an increase in concentration of the $\mathrm{H}^{+}$ion and changes in the concentrations of dissolved species $\left[\mathrm{CO}_{2}\right],\left[\mathrm{HCO}_{3}^{-}\right]$, and $\left[\mathrm{CO}_{3}^{2-}\right]$. Thus only a fraction of atmospheric $\mathrm{CO}_{2}$ gas becomes dissolved $\left[\mathrm{CO}_{2}\right]$ at equilibrium with the atmosphere, whereas most of the increase goes into the bicarbonate ion, increasing DIC. The increase in DIC at 25 and $5^{\circ}$ is, from Table 2 :

$$
\begin{aligned}
\Delta[\mathrm{DIC}] & =[\mathrm{DIC}]_{P_{\mathrm{CO}_{2}}=370-[\mathrm{DIC}]_{P_{\mathrm{CO}_{2}}=280}} \\
& =2.162 \times 10^{-3}-2.092 \times 10^{-3}=6.9 \times 10^{-5} \mathrm{molC} / \mathrm{kg} \text { at } 25^{\circ} \mathrm{C} \\
& =2.352 \times 10^{-3}-2.300 \times 10^{-3}=5.2 \times 10^{-5} \mathrm{molC} / \mathrm{kg} \text { at } 5^{\circ} \mathrm{C} .
\end{aligned}
$$

The thickness of the surface ocean layer that takes up $\mathrm{CO}_{2}$ from the atmosphere depends on the mass of carbon transferred from the atmosphere, as cited at the beginning of Sect. $6, \Delta n_{a} \approx 1 \times 10^{16} \mathrm{~mol} \mathrm{C}$, and the increase in DIC concentration within a water layer of mass $M_{w}$ :

$\Delta n_{a}=\Delta[\mathrm{DIC}] \times M_{w}(\mathrm{molC})$.

Thus the thickness of the surface ocean layer, $h$, where dissolved $\mathrm{CO}_{2}$ is equilibrated with the atmosphere, is from Eq. (18):

$h_{25^{\circ} \mathrm{C}}=\left(1 \times 10^{16} \mathrm{molC}\right) /\left(6.9 \times 10^{-5} \times 1027 \times 3.61 \times 10^{14}\right)=390 \mathrm{~m}$ $h_{5^{\circ} \mathrm{C}}=\left(1 \times 10^{16} \mathrm{molC}\right) /\left(5.2 \times 10^{-5} \times 1027 \times 3.61 \times 10^{14}\right)=518 \mathrm{~m}$,

where the mean density of ocean water is taken as $1027 \mathrm{~kg} / \mathrm{m}^{3}$ and ocean surface area is $3.61 \times 10^{14} \mathrm{~m}^{2}$.

The above results for a 390 to 520-m-thick surface ocean layer are constrained by an external estimate of the carbon mass transferred to the ocean in industrial time, about $1 \times 10^{16} \mathrm{~mol} \mathrm{C}$, and by our conceptual model that assumes an equilibrium between atmospheric and dissolved $\mathrm{CO}_{2}$ in a water layer where total alkalinity remained constant (compare this model of the surface layer with Fig. 3 that shows carbon flows in the coastal zone). Lower total alkalinity would increase the surface layer thickness, at the same mass of industrial-age $\mathrm{CO}_{2}$ stored in the ocean: at the total alkalinity value of $2.300 \times 10^{-3}$ instead of $2.544 \times 10^{-3}$ used in the above computation and Table 3 , the surface layer thickness would be about $430 \mathrm{~m}$ at $25^{\circ} \mathrm{C}$ or $580 \mathrm{~m}$ at $5^{\circ} \mathrm{C}$.

In a 400 to 500 -m-thick water layer, the mass of DIC in pre-industrial time was between 31 and $43 \times 10^{16} \mathrm{~mol} \mathrm{C}$, and it increased by $1 \times 10^{16} \mathrm{~mol}$ at the expense of atmospheric $\mathrm{CO}_{2}$ in 300 years. In the same period, the mass of carbon supplied by rivers to the ocean would have been between $0.4 \times 10^{16}$ and $1 \times 10^{16} \mathrm{~mol} \mathrm{C}$ : this estimate is based on the $\mathrm{HCO}_{3}^{-}$ion concentration in rivers from $23 \mathrm{mg} / \mathrm{kg}\left(\mathrm{HCO}_{3}^{-}\right.$ 
from dissolution of carbonate rocks only; Drever, 1988; Mackenzie, 1992) to a total concentration of $52 \mathrm{mg} / \mathrm{kg}$ (Livingston, 1963; Mackenzie and Garrels, 1971; Drever, 1998; Berner and Berner, 1996), and a global water discharge to the ocean of $3.74 \times 10^{16} \mathrm{~kg} / \mathrm{yr}$ (Baumgartner and Reichel, 1975; Meybeck, 1979, 1984; Gleick, 1993). Net removal rate of $\mathrm{CaCO}_{3}$ from ocean water is its storage in shallow and deepwater sediments at the rate of $32.1 \times 10^{12} \mathrm{~mol} / \mathrm{yr}$ (Fig. 2b) and corresponds to removal in 300 years of nearly $1 \times 10^{16} \mathrm{~mol} \mathrm{C}$ from ocean water. This seeming balance of inorganic carbon input and removal is not supported by the estimates of $\mathrm{CO}_{2}$ evasion from the ocean (Fig. 2b) that, although not addressing the industrial rise of atmospheric $\mathrm{CO}_{2}$, indicate the inorganic carbon input as being less than needed to account for the $\mathrm{CaCO}_{3}$ precipitation. Similarly, the delivery of organic carbon by rivers at the rate of 26 to $34 \times 10^{12} \mathrm{~mol} / \mathrm{yr}$ (Ver et al., 1999; Fig. 2a) produces in 300 years an input of 0.8 to $1 \times 10^{16} \mathrm{~mol} \mathrm{C}$. Its storage as organic matter in sediments at the rate of 8 to $16 \times 10^{12} \mathrm{~mol} / \mathrm{yr}$ (Ver et al., 1999; Fig. 2a) corresponds to removal of 0.2 to $0.5 \times 10^{16} \mathrm{~mol} \mathrm{C}$ from ocean water in 300 years.

The preceding estimates suggest that addition of inorganic and organic carbon from land to the ocean in the past 300 years was 1.8 to $2.0 \times 10^{16} \mathrm{~mol} \mathrm{C}$, which is close to, but possibly somewhat greater than, the removal of carbonate and organic carbon by net storage in sediments, 1.2 to $1.5 \times 10^{16}$ mol C. Despite the uncertainties in these estimates of the in and out carbon fluxes, the evasion flux of $\mathrm{CO}_{2}$, and the nature of our air-water exchange model for the industrial age, we reiterate that the calculated mass of $\mathrm{CO}_{2}$ taken up by a surface ocean layer is a baseline estimate for a system that is close to balance with respect to land inputs and sediment storage over 300 years.

6.3 Air-sea $\mathrm{CO}_{2}$ exchange in the shallow-water ocean environment

In the coastal zone, the large inflows of the nutrients by rivers and coastal upwelling make the intensity and rates of processes controlling the carbon cycle within it and the air-sea $\mathrm{CO}_{2}$ exchange different from the open ocean. In this section, we comment on the air-sea $\mathrm{CO}_{2}$ exchange in the shallowwater ocean environment (bays, estuaries, lagoons, banks, continental shelf), based on a model described in detail elsewhere (Shallow-water Ocean Carbonate Model, SOCM; Andersson et al., 2003, Andersson and Mackenzie, 2004).

The major forcings of this model are the rising atmospheric $\mathrm{CO}_{2}$ concentrations and temperature (Fig. 5) according to the IPCC IS92a scenario (Enting et al., 1995). Inputs of organic and inorganic carbon and nutrients $(\mathrm{N}$ and P) via rivers and runoff (Fig. 5) are based on observational data and model predictions from the Terrestrial Ocean aTmosphere Ecosystem Model (TOTEM; e.g. Ver et al., 1999; Mackenzie et al., 2001). Other important parameters of the model are net ecosystem production (NEP and NEP*), de-

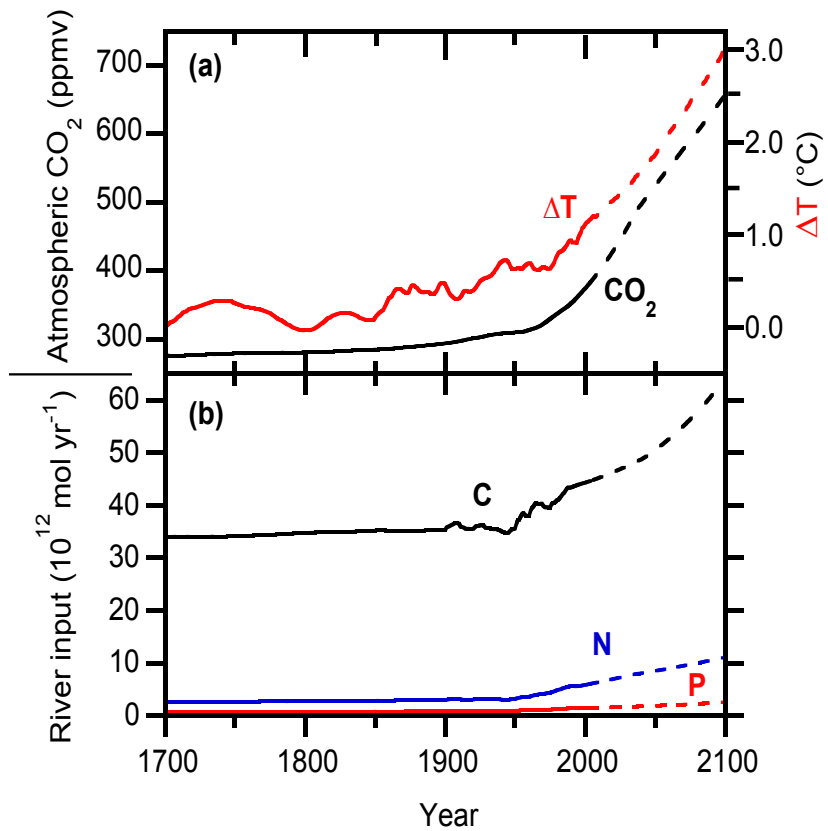

Fig. 5. Major forcings of the Shallow-water Ocean Carbonate Model (SOCM). (a) Atmospheric $\mathrm{CO}_{2}$ concentration (ppmv) and temperature rise $\Delta \mathrm{T}\left({ }^{\circ} \mathrm{C}\right)$ from the year 1700 to 2000 with projections for the 21st century according to the IPCC IS92a scenario (Enting et al., 1995). (b) Riverine inputs of organic C, N, and P to the coastal zone in industrial time based on observational data and model predictions using the Terrestrial Ocean aTmosphere Ecosystem Model (Tотем, Ver at al., 1999). The organic species include dissolved, reactive particulate, and refractive particulate fractions (results of TOTEM computations, Mackenzie et al., 2001).

fined in Eqs. (10) and (11), and net ecosystem calcification (NEC), taken as the difference between $\mathrm{CaCO}_{3}$ precipitation and dissolution rates (Fig. 2b). Biogenic carbonate production, generally known to depend on the saturation state of coastal ocean water with respect to calcite, was related in the model to either a linear or a curvilinear dependence on the saturation state. Net gas transport of $\mathrm{CO}_{2}$ between the atmosphere and the surface water of the shallow-water ocean environment is a function of the above two biogeochemical processes and a change in atmospheric $\mathrm{CO}_{2}$, usually caused by other factors. The following equation describes net $\mathrm{CO}_{2}$ transport (Andersson and Mackenzie, 2004; see also Fig. 3):

$F=-\Psi \cdot \mathrm{NEC}+\mathrm{NEP}^{*}+F_{\mathrm{DIC}, \text { out }}-F_{\mathrm{DIC}, \text { in }}+\frac{d C_{\mathrm{DIC}}}{d t}$,

where $F$ is the $\mathrm{CO}_{2}$ flux in mol $\mathrm{C} \mathrm{yr}^{-1}, \Psi(\Psi>0)$ is the fraction of $\mathrm{CO}_{2}$ released to the atmosphere for each mole of $\mathrm{CaCO}_{3}$ precipitated (Frankignoulle et al., 1994), NEC and $\mathrm{NEP}^{*}$ are as defined previously, $F_{\mathrm{DIC}}$, out is the export of DIC from coastal water to the open ocean (flux $F_{\mathrm{i} 4}$ in Fig. 3), $F_{\text {DIC, in }}$ is the input of DIC from rivers and coastal upwelling (flux $F_{\mathrm{i} 1}+F_{\mathrm{i} 5}$ in Fig. 3), and the last term relates atmospheric and ocean-water carbon content through the modified Rev- 
elle factor given below. In the initial quasi-steady state of the model for the year 1700 (Fig. 6), NEC is positive, NEP* is negative, and $d C_{\mathrm{DIC}} / d t$ is zero, reflecting $\mathrm{CO}_{2}$ fluxes to the atmosphere from net ecosystem calcification and net ecosystem production. Under these conditions, flux $F$ in Eq. (19) is negative DIC input from land and coastal upwelling is greater than its export to the open ocean (Ver et al., 1999), and this is consistent with its sign as shown in Fig. 3.

In Eq. (19), the variable $C_{\text {DIC }}$ is the DIC concentration or mass in ocean water that depends on the atmospheric $\mathrm{CO}_{2}$ concentration. Bacastow and Keeling (1973) calculated the $\mathrm{CO}_{2}$ concentration in ocean water as a function of the atmospheric concentration in a form of the ratio

$R=\frac{C_{\text {atm }, \mathrm{t}} / C_{\text {atm }, 0}-1}{C_{\text {DIC }, \mathrm{t}} / C_{\text {DIC }, 0}-1}$

where subscript $t$ is the concentration at time $t$ and subscript 0 denotes the initial value at $t=0$. This $R$ was calculated by Bacastow and Keeling (1973) for an average surface ocean water of total alkalinity $2.435 \times 10^{-3}$ mol-equivalent/liter, temperature $19.59^{\circ} \mathrm{C}$, chlorinity 19.24 per mil, and initial $\mathrm{pH}=8.271$. Revelle and Munk (1977) approximated $R$ in Eq. (20) by a linear relationship:

$R \approx R_{0}+d \times\left(C_{\text {atm }, t} / C_{\text {atm }, 0}-1\right)$

with the constants $R_{0}=9$ and $d=4$. Subsequently, $R$ became known as the Revelle factor and its different forms have been discussed by Zeebe and Wolf-Gladrow (2001). The initial Revelle factor $\left(R_{0}\right)$ equal to 9 indicates that the buffer mechanism of the seawater causes a fractional rise of DIC in the surface waters that is one-ninth of the increase in the atmosphere (Revelle and Munk 1977). The time-dependent change $d C_{\text {DIC }} / d t$ in Eq. (19) is obtained by differentiation of Eqs. (20) and (21), giving simpler approximate relationship (22) and a more complete relationship (23) with a secondorder term:

$$
\begin{aligned}
& \frac{d C_{\mathrm{DIC}}}{d t}=\frac{C_{\mathrm{DIC}, 0}}{R_{0} C_{\mathrm{atm}, 0}+d \times\left(C_{\mathrm{atm}, \mathrm{t}}-C_{\mathrm{atm}, 0}\right)} \times \frac{d C_{\mathrm{atm}}}{d t} \\
& \frac{d C_{\mathrm{DIC}}}{d t}= \\
& \left\{\frac{C_{\mathrm{DIC}, 0}}{R_{0} C_{\mathrm{atm}, 0}+d \times\left(C_{\mathrm{atm}, \mathrm{t}}-C_{\mathrm{atm}, 0}\right)}-\right. \\
& \left.\frac{d \times C_{\mathrm{DIC}, 0} \times\left(C_{\mathrm{atm}, \mathrm{t}}-C_{\mathrm{atm}, 0}\right)}{\left[R_{0} C_{\mathrm{atm}, 0}+d \times\left(C_{\mathrm{atm}, \mathrm{t}}-C_{\mathrm{atm}, 0}\right)\right]^{2}}\right\} \times \frac{d C_{\mathrm{atm}}}{d t} .
\end{aligned}
$$

At the initial condition of the model simulation in the year 1700, the shallow-water ocean environment was assumed to be in a quasi-steady state condition. At that time, the region was assumed to be a net source of approximately $-22 \times 10^{12}$ mol $\mathrm{CO}_{2} \mathrm{yr}^{-1}$ to the atmosphere owing to a net ecosystem calcification of $18.5 \mathrm{~mol} \mathrm{CO}_{2} \mathrm{yr}^{-1}$, leading to an evasion of approximately $-15 \times 10^{12} \mathrm{~mol} \mathrm{CO}_{2} \mathrm{yr}^{-1}$ to the atmosphere (Wollast 1998; see also Fig. 2b) and a net ecosystem metabolism of $-7 \times 10^{12} \mathrm{~mol} \mathrm{CO}_{2} \mathrm{yr}^{-1}$ (Smith and Hollibaugh, 1993) (Fig. 6). It is important to note that substantial uncertainty is associated with these estimates of the initial conditions.

Net ecosystem calcification decreased owing to decreased production (7 to 44\%) and increased dissolution of calcium carbonate between year 1700 and year 2100 (Fig. 6). If, following Frankignoulle et al. (1994), the number of moles of $\mathrm{CO}_{2}$ released to the atmosphere for every mole $\mathrm{CaCO}_{3}$ precipitated was approximately $0.6 \mathrm{~mol}$ at the initial conditions $\left(P_{\mathrm{CO}_{2}} \approx 280 \mathrm{ppmv}\right)$, and $0.75 \mathrm{~mol}\left(P_{\mathrm{CO}_{2}} \approx 700 \mathrm{ppmv}\right)$ at the end of the simulation, the flux of $\mathrm{CO}_{2}$ to the atmosphere owing to this process remained relatively unchanged or decreased by about $5 \times 10^{12} \mathrm{~mol} \mathrm{C} \mathrm{yr}^{-1}$. Although this decrease could be considered as a negative feedback to increasing atmospheric $\mathrm{CO}_{2}$, its magnitude is insignificant relative to the total invasion of anthropogenic $\mathrm{CO}_{2}$ into the ocean $\left(\sim 170 \times 10^{12} \mathrm{~mol} \mathrm{C} \mathrm{yr}^{-1}\right.$ at the beginning of the 21 st century).

Based on these changes in net ecosystem metabolism and calcification, and also changes in atmospheric $\mathrm{CO}_{2}$ content, the results of the numerical simulations suggest that the shallow-water ocean environment has served as a net source of $\mathrm{CO}_{2}$ to the atmosphere throughout at least part of the past 300 years (Fig. 6). However, its role as a source has significantly decreased, and the net flux is expected to reverse completely at some point in time or it is possible that this reversal has already taken place. Although significant uncertainty is associated with the magnitude of the initial air-sea $\mathrm{CO}_{2}$ exchange, the calculated trend is robust and representative for how this flux has changed direction and is likely to change in the future owing to anthropogenic activities.

Actual measurements of the air-sea $\mathrm{CO}_{2}$ flux from various global shallow water locations based on $\mathrm{CO}_{2}$ partial pressure and wind speed indicate that most regions where data were obtained act as a sink of atmospheric $\mathrm{CO}_{2}$ today (Table 4). However, some regions, such as estuaries, coral reefs and some upwelling regions, act as a source of $\mathrm{CO}_{2}$ to the atmosphere. Estuaries act as a source due to extensive deposition and remineralization of terrestrial organic matter. Coral reefs are considered to be slightly net autotrophic but still act as a source of $\mathrm{CO}_{2}$ owing to the process of calcification. Globally, coral reefs are responsible for a net flux of about

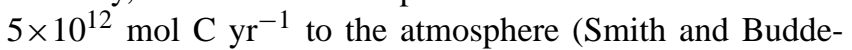
meier, 1992).

Upwelled waters are colder and contain a higher concentration of dissolved inorganic carbon than surface waters due to extensive remineralization of organic matter settling out from the surface water to the deep ocean. As these waters upwell and onwell on to the shelf, temperature and pressure change, and the solubility of $\mathrm{CO}_{2}$ decreases, generally resulting in a flux of $\mathrm{CO}_{2}$ to the atmosphere. This $\mathrm{CO}_{2}$ venting has been observed for example in the Northern Arabian Sea (Goyet et al., 1998). However, a recent study at Cape Perpetua, along the Oregon coast, which is a significant area of upwelling, indicated that this region, as opposed to other upwelling sections, acted as a significant sink of $\mathrm{CO}_{2}$ (Hales 
Table 4. Estimates of measured air-sea $\mathrm{CO}_{2}$ exchange from worldwide shallow-water locations (estuaries, reefs, shelves). Negative values denote $\mathrm{CO}_{2}$ flux from ocean to atmosphere; positive values denote flux from atmosphere to ocean*

\begin{tabular}{lcl}
\hline Location/region & net $\mathrm{CO}_{2}$ flux $\left(\mathrm{mol} \mathrm{C} \mathrm{m}^{-2} \mathrm{yr}^{-1}\right)$ & Reference \\
\hline Hog Reef flat, Bermuda & -1.20 & Bates et al. (2001) \\
New Jersey & +0.43 to +0.84 & Boehme et al. (1998) \\
Galician Coast & +0.66 to +1.17 & Borges and Frankignoulle (2001) \\
Scheldt Estuarine plume & -1.10 to -1.90 & Borges and Frankignoulle (2002) \\
South Atlantic Bight (SAB) & -2.50 & Cai et al. (2003) \\
Mid Atlantic Bight (MAB) & +1.00 & DeGrandpre et al. (2002) \\
Gulf of Calvi & -2.33 & Frankignoulle (1988) \\
Gulf of Biscay & +1.75 to +2.88 & Frankignoulle and Borges (2001) \\
European estuaries (Elbe, Ems, & & \\
Rhine, Scheldt, Tamar, Thames, & -36.5 to -277 & Frankignoulle et al. (1998) \\
Gironde, Duoro, Sado) & & \\
Moorea, French Polynesia & -0.55 & Gattuso et al. (1993) \\
Northern Arabian Sea & -0.46 & Goyet et al. (1998) \\
Cape Perpetua & +7.29 & Hales et al. (2003) \\
North Sea & +1.35 & Kempe and Pegler (1991) \\
Baltic Sea & +0.90 & Thomas and Schneider (1999) \\
East China Sea & +2.91 & Tsunogai et al. (1999) \\
East China Sea & +1.20 to +2.80 & Wang et al. (2000) \\
\hline
\end{tabular}

* It is important to realize that some of the estimates represent annual integrated flux measurements and others monthly or occasional measurements.

et al., 2003). The authors suggested that production in the region was only limited by available nitrate resulting in consumption of nitrate and $\mathrm{CO}_{2}$ in stoichiometric proportions. In addition, the upwelled waters had very high total alkalinity and pre-formed nitrate relative to their total dissolved inorganic carbon content and were subject to only moderate warming and changes in $\mathrm{CO}_{2}$ solubility because of the relatively high latitude and mild temperatures of this region.

Results from the European continental shelf (Frankignoulle and Borges, 2001; Kempe and Pegler, 1991), the East China Sea (Tsunogai et al., 1999; Wang et al., 2000), and certain parts of the U.S. continental shelf (Boehme et al., 1998; DeGrandpre et al., 2002) strongly agree with one another and suggest that continental shelves globally act as a significant sink of atmospheric $\mathrm{CO}_{2}$. Based on observations from the East China Sea, Tsunogai et al. (1999) proposed the existence of a global continental shelf pump that theoretically could remove as much as $1 \mathrm{Gt} \mathrm{C/yr}\left(+83 \times 10^{12} \mathrm{~mol} \mathrm{C/yr}\right)$ from the atmosphere, which corresponds to about $15 \%$ of the $\mathrm{CO}_{2}$ released annually from human activities. Opposed to these observations, a recent study from the South Atlantic Bight indicates that this continental shelf region acts as a significant source of $\mathrm{CO}_{2}$ to the atmosphere (Cai et al., 2003). The authors suggested that extensive export and remineralization of organic matter from nearby salt-marshes could account for this observed flux.

Based on the current data available in the literature, it is not possible to conclude unequivocally whether or not the global shallow-water ocean environment acts as a sink or a source of atmospheric $\mathrm{CO}_{2}$, although most results point towards this region being a sink (Ducklow and McCallister, 2004). Similarly, from a modeling perspective we cannot conclude whether this region now is a sink or a source, but we can predict the trend of how air-sea exchange has changed from the past to the present and how it is likely to change in the future owing to human alterations of the environment. In the context of global change, these trends could be important because of the significance of the shallow-water ocean environment on a global scale and the disproportional effect of human activities on this region.

\section{Conclusions}

The studies of the carbon cycle at various time and space scales had a long and often confusing history. The ocean environment as a whole has in the past apparently served as a net source of $\mathrm{CO}_{2}$ to the atmosphere on the geological time scale of millennia or longer; otherwise, the land-derived carbon delivered to the oceans would have accumulated there and led to a draw-down of atmospheric $\mathrm{CO}_{2}$ in several thousand years (all other factors remaining constant). In the past 300 years of industrial time, the rise in $\mathrm{CO}_{2}$ emissions from human activities on land to the atmosphere resulted in the distribution of added $\mathrm{CO}_{2}$ among the atmosphere, land, and ocean. The rising atmospheric $\mathrm{CO}_{2}$ has resulted in its uptake by a surface ocean layer equivalent to a thickness of 400 to 


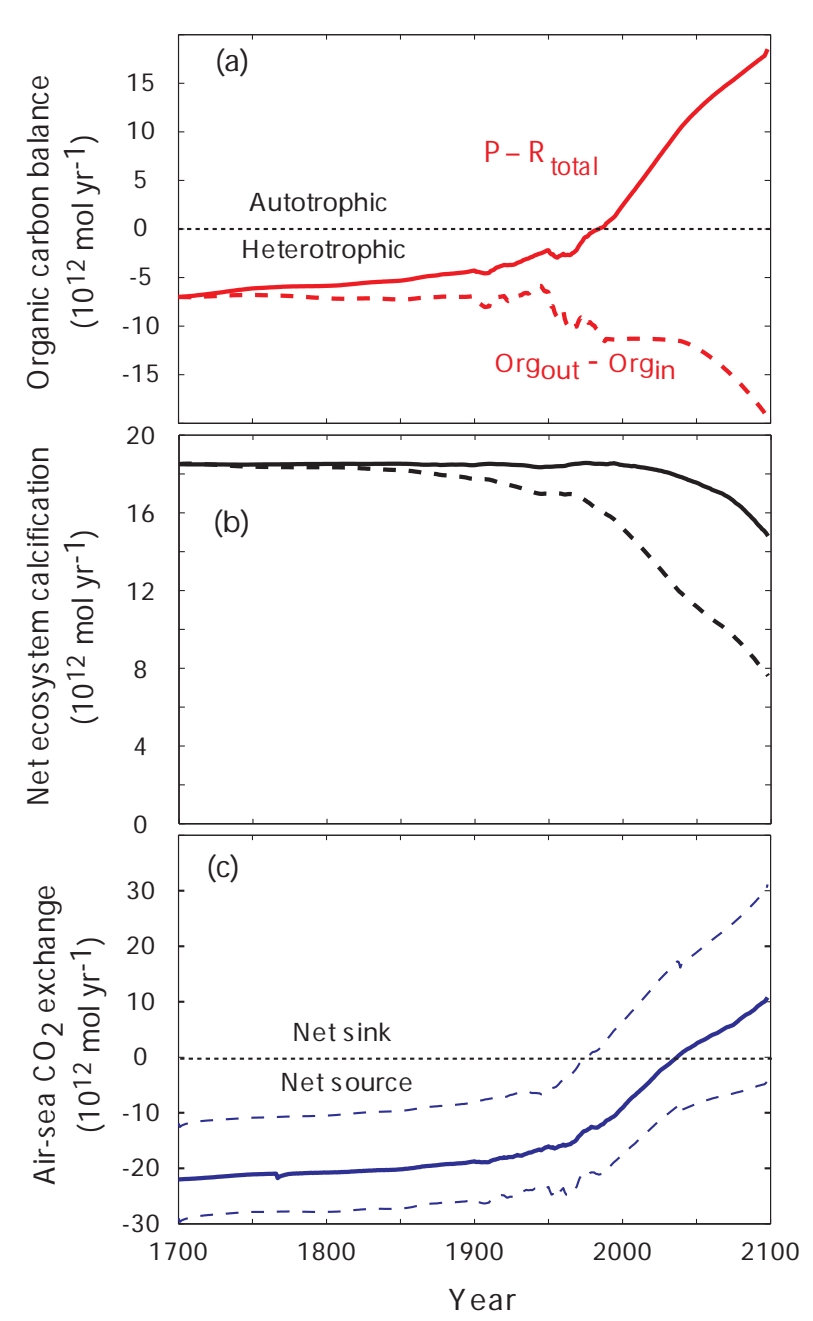

Fig. 6. Numerical results of the Shallow-water Ocean Carbonate Model (SOCM) simulation for the period 1700 to 2000 with projections to 2100 . (a) Net ecosystem production expressed as total production minus total respiration $\left(\mathrm{P}-\mathrm{R}_{\text {total }}\right.$ or NEP*, see text) and $\mathrm{Org}_{\text {out }}-\mathrm{Org}_{\text {in }}$ (NEP, see text). The difference between the two curves represents changes in the total organic carbon reservoir concentration, hence mass, over time $\left(\Delta C_{\text {org }}\right)$ of the shallow-water ocean environment (i.e. $d C_{\text {org }} / d t$ in Eq. (9) does not equal 0). (b) Net ecosystem calcification (NEC), the difference between precipitation and dissolution rates of $\mathrm{CaCO}_{3}$. The two curves represent two scenarios: a linear (solid line) or a curvilinear (dashed line) relationship between biogenic calcification rate and calcite saturation state. (c) Net air-sea exchange of $\mathrm{CO}_{2}$ due to the historical and projected rise in atmospheric $\mathrm{CO}_{2}$ and imbalances in the organic and inorganic carbon cycles in the ocean. The "best" estimate is illustrated by the solid line and the upper and lower bounding dashed lines represent the range of results obtained from model numerical simulations that include a $50 \%$ uncertainty in the organic carbon balance in the ocean, and minimum and maximum estimates of calcification responses to increasing temperature and rising atmospheric $\mathrm{CO}_{2}$ concentrations (lower carbonate saturation state) (discussion in the text and Andersson and Mackenzie, 2004).
$500 \mathrm{~m}$, lowering of the surface ocean water $\mathrm{pH}$ by about 0.1 unit, a slight increase in DIC concentration, and a decrease in the degree of saturation with respect to calcite. This result is a baseline estimate, at a range of temperature from 5 to $25^{\circ} \mathrm{C}$, of the $\mathrm{CO}_{2}$ partitioning between the atmosphere and surface ocean under the modelling assumptions discussed in the text. The historical situation of the direction and magnitude of the coastal vs. the open ocean with respect to net $\mathrm{CO}_{2}$ exchange is less clear. The model presented in this paper has a pre-industrial coastal zone that emits $\mathrm{CO}_{2}$ to the atmosphere because of the imbalances between gross primary production and respiration and the precipitation and accumulation of $\mathrm{CaCO}_{3}$. Model calculations also show that the coastal zone will switch or has switched to a net sink at some point in time as a consequence of anthropogenic $\mathrm{CO}_{2}$ emissions to the atmosphere. However, based on the numerical simulations of the model, it is not possible to say when this transition will happen or if it already has happened because the timing is dependent particularly on the magnitude of the flux estimates for pre-industrial time. These estimates depend on the net ecosystem production state of the coastal ocean and the rate of precipitation and accumulation of $\mathrm{CaCO}_{3}$, which are not well constrained historically. Most investigators (e.g. Smith and Hollibaugh, 1993; Tsunogai et al., 1999; Liu et al., 2000; Chen, 2003; Ducklow and McCallister, 2004) contend that the present-day coastal ocean (and of course the open ocean) is a net sink for atmospheric $\mathrm{CO}_{2}$. This is in agreement with the global modeling of the coastal zone presented here, especially if one considers net ecosystem production of the coastal ocean to be in a transient state, leading to NEP* developing historically from net heterotrophic to autotrophic during the past 300 years.

Acknowledgements. We recognize the late R. M. Garrels for his far-reaching contributions to our knowledge of the carbon cycle and for his efforts teaching FTM and AL how it operated. We are grateful to C. B. Gregor (Wright State University, Dayton, Ohio) for permission to reproduce his material in Fig. 1. We thank S. V. Smith (CICESE, Ensenada, Baja California, Mexico) for his editorial comments, and R. A. Berner (Yale University, New Haven, Conn.) and two anonymous reviewers for their critical and thoughtful reviews of the manuscript. We thank $\mathrm{C}$. Heinze (University of Bergen, Norway) and R. W. Buddemeier (University of Kansas, Lawrence, Kans.) for their insightful Interactive Comments that also gave us an opportunity to respond to some of the issues beyond the original scope of this paper (http://www.cosis.net/members/journals/df/article.php?a_id=826).

This research was supported by NSF grants EAR-0223509 and OAR-0002889 and additionally by the A. L. Howland Fund, Department of Geological Sciences, Northwestern University. This is School of Ocean and Earth Science and Technology, University of Hawaii, Contribution No. 6391.

Edited by: S. V. Smith 


\section{References}

Andersson, A. J.: Climate change and anthropogenic effects on shallow-water carbonate biogeochemistry, MS thesis, Univ. of Hawaii, Honolulu, Hawaii, 195, 2003.

Andersson, A. J. and Mackenzie, F. T.: The shallow-water ocean: a source or sink of atmospheric $\mathrm{CO}_{2}$ ? Front. Ecol. Environ., in press, 2004.

Andersson, A. J., Mackenzie, F. T., and Ver, L. M.: Solution of shallow-water carbonates: an insignificant buffer against rising atmospheric $\mathrm{CO}_{2}$, Geology, 31, 513-516, 2003.

Arvidson, R., Mackenzie, F. T., and Guidry, M.: MAGic: A Phanerozoic model for the geochemical cycling of major rockforming components, Amer. Jour. Sci., in press, 2004.

Barnes, D. J. and Cuff, C.: Solution of reef rock buffers seawater against rising atmospheric $\mathrm{CO}_{2}$. Proc. 9th Internat. Coral Reef Symp., Abstracts, edited by Hopley, D., Hopley, M., Tamelander, J., and Done, T., State Ministry for the Environment, Indonesia, 248, 2000.

Bassham, J. A.: Photosynthesis, Encycl. Brit., Macropaedia, 1974 edit., Univ. Chicago Press, Chicago, Ill., 14, 365-373, 1974.

Bates, N., Samuels, L., and Merlivat, L.: Biogeochemical and physical factors influencing seawater $f \mathrm{CO}_{2}$ and air-sea $\mathrm{CO}_{2}$ exchange on the Bermuda coral reef, Limnol. Oceanogr., 46, 833846, 2001.

Bauer, J. E., Williams, P. M., and Druffel, E. R. M.: Super ${ }^{14}$ C activity of dissolved organic carbon fractions in the north-central Pacific and Sargasso Sea, Nature, 357, 667-670, 1992.

Baumgartner, A. and Reichel, E.: The World Water Balance, R. Oldenburg Verlag, München, 181, 1975.

Becker, G. F.: The age of the earth, Smithsonian Misc. Collect. 56, 6-28, 1910.

Berger, W. H.: Increase of carbon dioxide in the atmosphere during deglaciation: The coral reef hypothesis, Naturwissenschaften, 69, 87-88, 1982.

Berner, R. A.: A model for atmospheric $\mathrm{CO}_{2}$ over Phanerozoic time, Amer. Jour. Sci., 291, 339-376, 1991.

Berner, R. A.: The Phanerozoic Carbon Cycle: $\mathrm{CO}_{2}$ and $\mathrm{O}_{2}$. Oxford Univ. Press, New York, in press, 2004.

Berner, R. A.: Geocarb II: A revised model of atmospheric $\mathrm{CO}_{2}$ over Phanerozoic time, Amer. Jour. Sci., 294, 56-91, 1994.

Berner, E. K. and Berner, R. A.: The Global Environment: Water, Air and Geochemical Cycles. Prentice-Hall, Upper Saddle River, NJ, 376, 1996.

Berner, R. A. and Canfield, D. E.: A new model for atmospheric oxygen over Phanerozoic time, Amer. Jour. Sci., 289, 333-361, 1989.

Berner, R. A. and Kothavala, Z.: Geocarb III: A revised model of atmospheric $\mathrm{CO}_{2}$ over Phanerozoic time, Amer. Jour. Sci., 301, 182-204, 2001.

Berner, R. A. and Maasch, K. A.: Chemical weathering and controls on atmospheric $\mathrm{O}_{2}$ and $\mathrm{CO}_{2}$ : fundamental principles were enunciated by J. J. Ebelmen in 1845, Geochim. Cosmochim. Acta, 60, 1633-1637, 1996.

Berner, R. A., Lasaga, A. C., and Garrels, R. M.: The carbonatesilicate geochemical cycle and its effect on atmospheric carbon dioxide over the past 100 million years, Amer. Jour. Sci., 283, 641-683, 1983.

Boehme, S. E., Sabine C. L., and Reimers, C. E.: $\mathrm{CO}_{2}$ fluxes from a coastal transect: A time series approach, Mar. Chem., 63, 49-67,
1998.

Borges, A. V. and Frankignoulle, M.: Distribution and air-water exchange of carbon dioxide in the Scheldt plume off the Belgian coast, Biogeochemistry, 59, 41-67, 2002.

Borges, A. V. and Frankignoulle, M.: Distribution of surface carbon dioxide and air-sea exchange in the upwelling system off the Galician coast, Global Biogeochem, Cycles, 16, doi:10.1029/2000GB001385, 2002.

Broecker, W. and Henderson, G.: The sequence of events surrounding Termination II and their implication for the cause of glacialinterglacial $\mathrm{CO}_{2}$ changes, Paleoceanography, 13, 352-364, 1998.

Bruno, M. and Joos, F.: Terrestrial carbon storage during the past 200 years. A Monte Carlo analysis of $\mathrm{CO}_{2}$ data from ice core and atmospheric measurements, Global Biogeochem. Cycles, 11, 111-124, 1997.

Cai, W.-J., Wang, Z. A., and Wang, Y.: The role of marshdominated heterotrophic continental margins in transport of $\mathrm{CO}_{2}$ between the atmosphere, the land-sea interface and the ocean, Geophys. Res. Lett., 30, 16, 1849, doi:10.1029/2003GL017633, 2003.

Carslaw, H. S. and Jaeger, J. C.: Conduction of Heat in Solids. 2nd ed., Oxford Univ. Press, Oxford, x + 510, 1959.

Chen, C.-T. A., Andreev, A., Kim, K.-R., and Yamamoto, M.: Roles of continental shelves and marginal seas in the biogeochemical cycles of the North Pacific Ocean, Jour. Oceanogr., 60, 17-44, 2004.

Chester, R.: Marine Geochemistry, Blackwell Science, Oxford, xiv $+506,2000$

Chung, S.-N., Park, G.-H., Lee, K., Key, R. M., Millero, F. J., Feely, R. A., Sabine, C. L., and Falkowski, P. G.: Postindustrial enhancement of aragonite undersaturation in the upper tropical and subtropical Atlantic Ocean: The role of anthropogenic $\mathrm{CO}_{2}$, Limnol. Oceanogr., 14, 2, 1-7, 2004.

Church, M., Ducklow, H. W., and Karl, D. M.: Temporal variability in dissolved organic matter stocks in the Central North Pacific Gyre, Limnol. Oceanogr., 47, 1-10, 2002.

Croll, J.: On a method of determining the mean thickness of the sedimentary rocks of the globe, Geol. Mag., 8, 97-102, 285-287, 1871.

DeGrandpre, M. D., Olbu, G. D., Beatty, C. M. and Hammar, T. R.: Air-sea $\mathrm{CO}_{2}$ fluxes on the U.S. Middle Atlantic Bight, Deep-Sea Res. II, 49, 4369-4385, 2002.

Drever, J. I.: The Geochemistry of Natural Waters, Prentice Hall, Englewood Cliffs, N. J., x + 437, 1988.

Duarte, C. M. and Agusti, S.: The $\mathrm{CO}_{2}$ balance of unproductive aquatic ecosystems, Science, 281, 234-236, 1998.

Duarte, C. M., Agusti, S., del Giorgio, P. A., and Cole, J. J.: Regional carbon imbalance in the oceans, Science, 284, 1735b, 1999.

Ducklow, H. W. and McAllister, S. L.: The biogeochemistry of carbon dioxide in the coastal oceans, in The Sea: The Global Coastal Ocean- Multi-scale Interdisciplinary Processes, edited by Robinson, A. R. and Brink, K., Harvard Univ. Press, 13, in press, 2004.

Enting, I. G., Wigley, T. M. L., and Heimann, M.: Intergovernmental Panel on Climate Change (IPCC), Working Group 1, 1994: Modelling Results Relating Future Atmospheric $\mathrm{CO}_{2}$ Concentrations to Industrial Emissions, ORNL/CDIAC DB1009, Carbon Dioxide Information Analysis Center, U.S. Department of 
Energy, Oak Ridge National Laboratory, Oak Ridge, Tennessee, USA, 1995.

Fisher, O.: An estimate of the geological age of the earth, by J. Joly, M. A. et al., Geol. Mag., Decade 4 (New Series), 7, 124-132, 1900.

Frankignoulle, M. and Borges, A. V.: European continental shelf as a significant sink for atmospheric carbon dioxide, Global Biogeochem. Cycles, 15, 569-576, 2001.

Frankignoulle, M.: Field measurements of air-sea $\mathrm{CO}_{2}$ exchange, Limnol. Oceanogr., 33, 313-322, 1988.

Frankignoulle, M., Canon, C., and Gattuso, J.-P.: Marine calcification as a source of carbon dioxide: Positive feedback of increasing atmospheric $\mathrm{CO}_{2}$, Limnol. Oceanogr., 39, 458-462, 1994.

Frankignoulle, M., Abril, G., Borges, A., Bourge, I., Canon, C., DeLille, B., Libert, E., and Théate, J.-M.: Carbon dioxide emission from European estuaries, Science, 282, 434-436, 1998.

Gaffron, H.: Photosynthesis, Encycl. Brit., 1964 edit., Univ. Chicago Press, Chicago, Ill., 17, 855-856b, 1964.

Garrels, R. M. and Mackenzie, F. T.: Evolution of Sedimentary Rocks, Norton, New York, xvi + 397, 1971.

Garrels, R. M. and Mackenzie, F. T.: A quantitative model for the sedimentary rock cycle, Mar. Chem., 1, 27-41, 1972.

Garrels, R. M. and Mackenzie, F. T. (eds.): Some aspects of the role of the shallow ocean in global carbon dioxide uptake, U. S. Department of Energy Report CONF-8009140, NTIS, U. S. Department of Commerce, Springfield, Va., 46, 1981.

Garrels, R. M. and Perry, E. A., Jr.: Cycling of carbon, sulfur, and oxygen through geologic time, in The Sea: Marine Chemistry, edited by Goldberg, E. D., Wiley-Interscience, New York, 5, 303-306, 1974.

Gattuso, J.-P., Allemand, P. D., and Frankignoulle, M.: Interactions between the carbon and carbonate cycles at organism and community levels on coral reefs: A review of processes and control by carbonate chemistry, Amer. Zoolog., 39, 160-188, 1999.

Gattuso, J.-P., Frankignoulle, M., and Wollast, R.: Carbon and carbonate metabolism in coastal aquatic ecosystems, Ann. Rev. Ecol., 29, 405-434, 1998.

Gattuso, J.-P., Pichon, M., Delesalle, B., and Frankignoulle, M.: Community metabolism and air-sea $\mathrm{CO}_{2}$ fluxes in a coral reef ecosystem (Moorea, French Polynesia), Mar. Ecol. Progr. Ser., 96, 259-267, 1993.

Gleick, P. H. (ed.): Water in Crisis: A Guide to the World's Fresh Water Resources, Oxford Univ. Press, Oxford, xxiv + 473, 1993.

Goldberg, E. D.: Atmospheric dust, the sedimentary cycle and man, Geophysics, 1, 117-132, 1971

Goyet, C., Millero, F. J., O’Sullivan, D. W., Eischeid, G., McCue, S. J., and Bellerby, R. G. J.: Temporal variations of $p \mathrm{CO}_{2}$ in surface seawater of the Arabian Sea in 1995, Deep-Sea Res. I, 45, 609-623, 1998.

Gregor, C. B.: The rate of denudation in Post-Algonkian time, Koninkl. Ned. Akad. Wetenschap. Proc., 71, 22-30, 1968.

Gregor, C. B.: Denudation of the continents, Nature, 228, 273-275, 1970.

Gregor, C. B.: Weathering rates of sedimentary and crystalline rocks, Koninkl. Ned. Akad. Wetenschap. Proc., Ser. B, Phys. Sci., 83, 173-181, 1980.

Gregor, C. B.: Prologue: cyclic processes in geology, a historical sketch, in Chemical Cycles in the Evolution of the Earth, edited by Gregor, C. B., Garrels, R. M., Mackenzie, F. T., and Maynard,
J. B., Wiley, New York, 5-16, 1988.

Gregor, C. B.: Some ideas on the rock cycle: 1788-1988, Geochim. Cosmochim. Acta, 56, 2993-3000, 1992.

Hales, B., Bandstra, L., Takahashi, T., Covert, P., and Jennings, J.: The Oregon coastal ocean: A sink for Atmospheric $\mathrm{CO}_{2}$ ? Newsletter of Coastal Ocean Processes, 17, 4-5, 2003.

Halley, R. B. and Yates, K. K.: Will reef sediments buffer corals from increased global $\mathrm{CO}_{2}$, Proc. 9th Internat. Coral Reef Symp., Abstracts, edited by Hopley, D., Hopley, M., Tamelander, J., and Done, T., State Ministry for the Environment, Indonesia, 248, 2000.

Hawaiian Ocean Time series (HOTs): http://hahana.soest.hawaii. edu/hot/hot_jgofs.html, 2003.

Holland, H. D.: The Chemistry of the Atmosphere and Oceans, Wiley, New York, xvi + 351, 1978.

Hudson, R. J. M., Gherini, S. A., and Goldstein, R. A.: Modeling the global carbon cycle: Nitrogen fertilization of the terrestrial biosphere and the "missing" $\mathrm{CO}_{2}$ sink, Global Biogeochem. $\mathrm{Cy}$ cles, 8, 307-333, 1994.

Houghton, J. T., Ding, Y., Griggs, D. J., Noguer, M., van der Linden, P. J., Dai, X., Maskell, K., and Johnson, C. A. (eds.): Climate change 2001: The scientific basis, Contribution of Working Group I to the Third Assessment Report of the Intergovernmental Panel on Climate Change, Cambridge Univ. Press, Cambridge, 881, 2001.

Houghton, J. T., Meiro Filho, L. G., Callander, B. A., Harris, N., Kattenberg, A., and Maskell, K. (eds.): Climate change 1995: The science of climate change, Contribution of working group I to the Second Assessment Report of the intergovernmental Panel on Climate Change, Cambridge Univ. Press, Cambridge, 572, 1996.

Hunt, T. S.: Chemical and Geological Essays, Boston and London, (cited in Gregor, 1988), 1875.

Iglesias-Rodriguez, M. D., Armstrong, R., Feely, R., Hood, R., Kleypas, J., Milliman, J. D., Sabine, C., and Sarmiento, J.: Progress made in study of ocean's calcium carbonate budget, EOS Amer. Geophys. Un. Trans., 83 (34), 365 and 374-375, 2002.

Joly, J.: An estimate of the geological age of the earth, Royal Dublin Soc., Sci. Trans., 2, 7, 23-66, 1899.

Keir, R. S. and Berger, W. H.: Late Holocene carbonate dissolution in the equatorial Pacific: reef growth or Neoglaciation?, in The Carbon Cycle and Atmospheric $\mathrm{CO}_{2}$ : Natural Variations Archean to Present, edited by Sundquist, E. T. and Broecker, W. S., Amer. Geophys. Un., Geophys. Monogr., 32, 208-219, 1985.

Kempe, S. and Pegler, K.: Sinks and sources of $\mathrm{CO}_{2}$ in coastal seas: the North Sea, Tellus, 43B, 224-235, 1991.

Kerrick, D. M., McKibben, M. A., Seward, T. M., and Caldeira, $\mathrm{K}$.: Convective hydrothermal $\mathrm{CO}_{2}$ emission from high heat flow regions, Chem. Geol., 121, 285-293, 1995.

Kleypas, J. A., Buddemeier, R. W., Archer, D., Gattuso, J.-P., Langdon, C., and Opdyke, B. N.: Geochemical consequences of increased atmospheric carbon dioxide on coral reefs, Science, 284, 118-120, 1999.

Kleypas, J. A., Buddemeier, R. W., and Gattuso, J.-P.: The future of coral reefs in an age of global change, Internat. Jour. Earth. Sci. (Geol. Rundschau), 90: 426-437, 2001.

Langdon, C., Takahashi, T., Sweeney, C., Chipman, D., Goddard, J., Marubini, F., Aceves, H., Barnett, H., and Atkinson, M.: Effect 
of calcium carbonate saturation state on the calcification rate of an experimental coral reef, Global Biogeochem. Cycles, 14, 639$654,2000$.

Lasaga, A. C., Berner, R. A., and Garrels R. M.: An improved geochemical model of atmospheric $\mathrm{CO}_{2}$ fluctuations over the past 100 million years, in The Carbon Cycle and Atmospheric $\mathrm{CO}_{2}$ : Natural Variations Archean to Present edited by Sundquist, E. and Broecker, W. S., Amer. Geophys. Un., Geophys. Monogr., 32, 397-411, 1985.

Leclercq, N., Gattuso, J.-P., and Jaubert, J.: $\mathrm{CO}_{2}$ partial pressure controls the calcification rate of a coral community, Global Change Biol., 6, 329-334, 2000.

Leclercq, N., Gattuso, J.-P., and Jaubert, J.: Primary production, respiration, and calcification of a coral reef mesocosm under increased $\mathrm{CO}_{2}$ partial pressure, Limnol. Oceanogr., 47, 558-564, 2002.

Lee, C.: Controls on organic carbon preservation: the use of stratified water bodies to compare intrinsic rates of decomposition in oxic and anoxic systems. Geochim. Cosmochim. Acta, 56, 33233335, 1992.

Lerman, A., Mackenzie, F. T., and Garrels, R. M.: Modelling of geochemical cycles: phosphorus as an example, Geol. Soc. Am. Mem., 142, 205-218, 1975.

Lerman, A., Mackenzie, F. T., and Geiger, R. J.: Environmental chemical stress effects associated with the carbon and phosphorus biogeochemical cycles, in Ecotoxicology: Problems and Approaches, edited by Levin, S. A., Harwell, M. A., Kelly, J. R., and Kimball, K. D., Springer-Verlag, New York, 315-350, 1989.

Lerman, A., Mackenzie, F. T., and Ver, L. M.: Coupling of the perturbed C-N-P cycles in industrial time, Aquatic Geochem., in press, 2004.

Li, Y.-H.: A Compendium of Geochemistry, Princeton Univ. Press, Princeton, N. J., xiv + 475, 2000.

Linsey, R. K.: Hydrology. Encycl. Brit., 1964 edit., Univ. Chicago Press, Chicago, Ill., 11, 959-961, 1964.

Liu, K. K., Iseki, K., and Chao, S.-Y.: Continental margin carbon fluxes, in The Changing Ocean Carbon Cycle, edited by Hanson, R. B., Ducklow, H. W., and Field, J. G., Cambridge Univ. Press, Cambridge, 187-239, 2000.

Livingston, D. A.: Chemical composition of rivers and lakes, U.S. Geol. Surv. Prof. Pap. 440-G, 64, 1963.

Lotka, A. J.: Elements of Physical Biology, Williams and Wilkins, Baltimore, Md., xxx $+460,1925$, published as Elements of Mathematical Biology, Dover, New York, xxx + 465, 1956.

Lyell, C.: Principles of Geology, John Murray, London, 1, xvi + 511, 1830, facsimile of 1st edit., Univ. Chicago Press, Chicago, Ill., 1990.

Lyell, C.: Principles of Geology, 11th edit., D. Appleton and Company, New York, 2, xx +652, 1872.

Lyell, C.: Principles of Geology, 12th edit., John Murray, London, 2, $\mathrm{xx}+652,1875$.

Mackenzie, F. T.: Chemical mass balance between rivers and oceans, in Encyclopedia of Earth System Science, Academic Press, New York, 1, 431-445, 1992.

Mackenzie, F. T.: Our Changing Planet: An Introduction to Earth System Science and Global Environmental Change, 3rd edit., Prentice-Hall, Upper Saddle River, N. J., xi + 580, 2003.

Mackenzie, F. T. and Pigott, J. P.: Tectonic controls of Phanerozoic sedimentary rock cycling, Jour. Geol. Soc. London, 138, 183-
196, 1981.

Mackenzie, F. T., Ver, L. M., Sabine, C., Lane, M., and Lerman, A.: C, N, P, S global biogeochemical cycles and modeling of global change, in Interactions of C, N, P and S Biogeochemical Cycles and Global Change, edited by Wollast, R., Mackenzie, F. T., and Chou, L., Springer-Verlag, Heidelberg, 1-62, 1993.

Mackenzie, F. T., Lerman, A., and Ver, L. M.: Role of the continental margin in the global carbon balance during the past three centuries, Geology, 26, 423-426, 1998.

Mackenzie, F. T., Ver, L. M., and Lerman, A.: Coastal-zone biogeochemical dynamics under global warming, Internat. Geol. Rev., 42, 193-206, 2000.

Mackenzie, F. T., Lerman, A., and Ver, L. M.: Recent past and future of the global carbon cycle, in Geological Perspectives of Global Climate Change edited by Gerhard, L. C., Harrison, W. E., and Hanson, B. M., Am. Assoc. Petroleum Geol. Studies in Geology, Am. Assoc. Petroleum Geologists, Tulsa, Oklahoma, 47, 51-82, 2001.

Mantoura, R. F. C., Martin, J. M., and Wollast, R. (eds.): Ocean Margin Processes in Global Change, Wiley, Chichester, UK, 469, 1991.

Meadows, D. H., Meadows, D. L., Randers, J., and Behrens III, W. W.: The Limits to Growth, Universe Books, New York, 205, 1972.

Meybeck, M.: Concentrations des eaux fluviales en éléments majeurs et apports en solution aux océans, Rev. Géol. Dyn. Géogr. Phys., 21, 3, 217-246, 1979.

Meybeck, M.: Carbon, nitrogen, and phosphorus transport by world rivers, Amer. Jour. Sci., 282, 401-450, 1982.

Meybeck, M.: Les fleuves et le cycle géochimique des éléments, Thèse de Doctorat d'État ès Sciences Naturelle, No 84-35, Univ. Pierre et Marie Curie, Paris, 1984.

Meyer, B. S.: Plant Physiology, Encycl. Brit., 1964 edit., Univ. Chicago Press, Chicago, Ill., 18, 16-31, 1964.

Milliken, K. L.: Late diagenesis and mass transfer in sandstoneshale sequences, in Treatise on Geochemistry: Sediments, Diagenesis and Sedimentary rocks, edited by Mackenzie, F. T., Holland, H. D., and Turekian, K. K., Elsevier, New York, 7, 159190, 2004.

Milliman, J. D.: Production and accumulation of calcium carbonate in the ocean: Budget of a nonsteady state, Global Biogeochem. Cycles, 7, 927-957, 1993.

Milliman, J. D. and Syvitski, J. P. M.: Geomorphic/tectonic control of sediment discharge to the ocean; the importance of small mountainous rivers, Jour. Geology, 100, 525-544, 1992.

Milliman, J. D., Troy, P. J., Balch, W. M., Adams, A. K., Li, Y.H., and Mackenzie, F. T.: Biologically mediated dissolution of calcium carbonate above the chemical lysocline?, Deep-Sea Res. I, 46, 1653-1669, 1999.

Mohr, F.: Geschichte der Erde, 2. Aufl., Verlag Max Cohen \& Sohn, Bonn, Germany, xx + 554, 1875.

Morse, J. W. and Mackenzie, F. T.: Geochemistry of Sedimentary Carbonates, Elsevier, New York, xvi + 707, 1990.

Mottl, M. J.: Partitioning of energy and mass fluxes between midocean ridge axes and flanks at high and low temperature, in Energy and Mass Transfer in Marine Hydrothermal Systems, edited by Halbach, P. E., Tunnicliffe, V., and Hein, J. R., Dahlem Univ. Press, Berlin, 271-286, 2003.

Mucci, A.: The solubility of calcite and aragonite in seawater at var- 
ious salinities, temperatures, and one atmosphere total pressure, Amer. Jour. Science, 283, 780-799, 1983.

Müller, P. J. and Suess, E.: Productivity, sedimentation rate, and sedimentary organic matter in the oceans, I. Organic carbon preservation, Deep-Sea Res., 26, 1347-1362, 1979.

Neumann, A. C.: Processes of recent carbonate sedimentation in Harrington sound, Bermuda, Bull. Mar. Sci., 15, 987-1035, 1965.

Odum, H. T.: Systems Ecology: An Introduction, Wiley, New York, $\mathrm{xv}+644,1983$

Opdyke, B. N. and Walker, J. C. G.: Return of the coral reef hypothesis: Basin to shelf partitioning of $\mathrm{CaCO}_{3}$ and its effect on atmospheric $\mathrm{CO}_{2}$, Geology, 20, 733-736, 1992.

Poldervaart, A.: Chemistry of the Earth's surface, in Crust of the Earth, edited by Poldervaart, A., Geol. Soc. America Spec. Pap., 62, 119-144, 1955.

Prospero, J. M.: Eolian transport to the World Ocean, in The Sea: The Oceanic Lithosphere, edited by Emiliani, C., Wiley, New York, 7, 801-874, 1981.

Rabouille, C., Mackenzie, F. T., and Ver, L. M.: Influence of the human perturbation on carbon, nitrogen, and oxygen biogeochemical cycles in the global coastal ocean, Geochim. Cosmochim. Acta, 65, 3615-3639, 2001.

Rankama, K. and Sahama, Th. G.: Geochemistry, Univ. Chicago Press, Chicago, Ill., xvi + 912, 1950.

Rea, D. K., Hovan, S. A., and Janecek, T. R.: Late Quaternary flux of eolian dust to the pelagic ocean, in Geomaterial Fluxes on the Surface of the Earth, edited by Hay, W. W., National Research Council, National Academy Press, Washington, D. C., 116-123, 1994.

Revelle, R. and Munk, W.: The carbon dioxide cycle and the biosphere, in Energy and Climate, edited by N. G. S. committee, National Academy Press, Washington, D. C., 140-158, 1977.

Riebesell, U., Zondervan, I., Rost, B., Tortell, P. D., Zeebe, R. E., and Morel, F. M. M.: Reduced calcification of marine plankton in response to increased atmospheric $\mathrm{CO}_{2}$, Nature, 407, 364-367, 2000.

Ronov, A. B.: Osadochnaya Obolochka Zemli (Kolichestvennyye Zakonomernosti Stroyeniya, Sostava i Evolyutsii), Nauka, Moscow, 80, 1980.

Rowley, D. B.: Rate of plate creation and destruction: $180 \mathrm{Ma}$ to present, Geol. Soc. America Bull., 114, 927-933, 2002.

Sarmiento, J. L., Orr, J. C., and Siegenthaler, U.: A perturbation simulation of $\mathrm{CO}_{2}$ uptake in an ocean general circulation model, Jour. Geophys. Res., 97, 3621-3645, 1992.

Schlesinger, W. H.: Biogeochemistry: An Analysis of Global Change, 2nd edit., Academic Press, New York, xiii + 588, 1997.

Schmalz, R. F. and Chave, K. E.: Calcium carbonate: affecting saturation in ocean waters of Bermuda, Science, 139, 1206-1207, 1963.

Smith, S. V. and Hollibaugh, J. T.: Coastal metabolism and the oceanic organic carbon balance, Rev. Geophys., 31, 75-89, 1993.

Smith, S. V. and Mackenzie, F. T.: The ocean as a net heterotrophic system: Implications from the carbon biogeochemical cycle, Global Biogeochem. Cycles, 1, 187-198, 1987.

Smith, S. V.: Net carbon metabolism of oceanic margins and estuaries, in Biotic Feedbacks in the Global Climatic System: Will the Warming Feed the Warming, edited by Woodwell, G. M. and Mackenzie, F. T., Oxford Univ. Press, New York, 251-262, 1995. Smith, S. V. and Buddemeier R. W.: Global change and coral reef ecosystems, Ann. Rev. Ecol., 23, 89-118, 1992.

Takahashi, T.: The carbon dioxide puzzle, Oceanus, 32, 22-29, 1989.

Thomas, H. and Schneider, B.: The seasonal cycle of carbon dioxide in Baltic Sea surface waters, Jour. Mar. Systems, 22, 53-67, 1999.

Tsunogai, S., Watanabe, S., and Sato, T.: Is there a "continental shelf pump" for the absorption of atmospheric $\mathrm{CO}_{2}$ ?, Tellus, 51B, 701-712, 1999.

Urey, H. C.: The Planets: Their Origin and Development, Yale Univ. Press, New Haven, Conn., xvii + 245, 1952.

Veizer, J.: The evolving exogenic cycle, in Chemical Cycles in the Evolution of the Earth, edited by Gregor, C. B., Garrels, R. M., Mackenzie F. T., and Maynard, J. B., Wiley, New York, 175-261, 1988.

Ver, L. M. B.: Global kinetic models of the coupled C, N, P, and $S$ biogeochemical cycles: implications for global environmental change, Ph.D. Dissertation, Univ. of Hawaii, Honolulu, xxii + 681, 1998.

Ver, L. M. B., Mackenzie, F. T., and Lerman, A.: Biogeochemical responses of the carbon cycle to natural and human perturbations: past, present and future, Amer. Jour. Sci., 299, 762-801, 1999.

Volk, T.: Sensitivity of climate and atmospheric $\mathrm{CO}_{2}$ to deep-ocean and shallow-ocean carbonate burial, Nature, 337, 637-640, 1989.

Walker, J. C. G. and Opdyke, B. N.: The influence of variable rates of shelf carbonate deposition on atmospheric carbon dioxide and pelagic sediments, Paleoceanography, 10, 415-427, 1995.

Wang, S.-L., Chen, C.-T. A., Hong, G.-H., and Chung, C.-S.: Carbon dioxide and related parameters in the East China Sea, Cont. Shelf, 20, 525-544, 2000.

Ware, J. R., Smith, S. V., and Reaka-Kudla, M. L.: Coral reefs: Sources or sinks of atmospheric $\mathrm{CO}_{2}$, Coral Reefs, 11, 127-130, 1992.

Whitmarsh, J. and Govindjee: The photosynthetic process, in Concepts in Photobiology: Photosynthesis and Photomorphogenesis, edited by Singhal, G. S., Renger, G., Soppory, S. K., Irrgang, K.D., and Govindjee, Kluwer Academic, Dordrecht, The Netherlands, 11-51, 1995.

Williams, P. J. le B. and Bower, D. G.: Determination of organic carbon balance in the oceans from field observations: a re-evaluation, Science, 284, 1735a, 1999.

Wilson, E. O.: Threats to biodiversity, in Managing Planet Earth, edited by Scientific American Editors, W. H. Freeman, New York, 49-60, 1990.

Winn, C. D., Li, Y.-H., Mackenzie, F. T., and Karl, D. M.: Rising surface ocean dissolved inorganic carbon at the Hawaii Ocean Time-series site, Mar. Chem., 60, 33-47, 1998.

Wollast, R. and Mackenzie, F. T.: Global biogeochemical cycles and climate, in Climate and Geo-Sciences, edited by Berger, A., Schneider S., and Duplessy, J. C., Kluwer Academic Publishers, 453-473, 1989.

Wollast, R.: The relative importance of bioremineralization and dissolution of $\mathrm{CaCO}_{3}$ in the global carbon cycle, in Past and Present Biomineralization Processes: Considerations about the Carbonate Cycle, edited by Doumenge, F., Allemand, D., and Toulemont, A., Musée Océanographique, Monaco, 13-34, 1994.

Wollast, R.: Evaluation and comparison of the global carbon cycle in the coastal zone and in the open ocean, in The Sea: The Global Coastal Ocean, edited by Brink, K. H. and Robinson, A. 
R., Wiley, New York, 10, 213-252, 1998.

Wollast, R., Garrels, R. M., and Mackenzie, F. T.: Calcite-seawater reactions in ocean surface waters, Amer. Jour. Sci., 280, 831848, 1980.

Wood, B. J., Pawley, A., and Frost, D. R.: Water and carbon in the Earth's mantle, Phil. Trans. Roy. Soc. London, ser. A, 354, 1495-1511, 1996.

Woodwell, G. M.: Biotic feedbacks from the warming of the Earth, in Biotic Feedbacks in the Global Climatic System: Will the Warming Feed the Warming, edited by Woodwell, G. M. and Mackenzie, F. T., Oxford Univ. Press, New York, 3-21, 1995.
Zeebe, R. E. and Wolf-Gladrow, D.: $\mathrm{CO}_{2}$ in Seawater: Equilibrium, Kinetics, Isotopes, Elsevier, New York, xiv + 346, 2001.

Zondervan, I., Zeebe, R. E., Rost, B., and Riebesell, U.: Decreasing marine biogenic calcification: A negative feedback on rising atmospheric $p \mathrm{CO}_{2}$, Global Biogeochem. Cycles, 15, 507-516, 2001. 